\title{
The private value of too-big-to-fail guarantees
}

Michiel J. Bijlsma

Remco J. M. Mocking 



\title{
The private value of too-big-to-fail guarantees
}

\author{
Michiel J. Bijlsma ${ }^{1}$, Remco J.M. Mocking ${ }^{2}$
}

\begin{abstract}
We estimate the size of the annual funding advantage for a sample of 151 large European banks over the period 1-1-2008 until 15-6-2012 using rating agencies' assessment of banks' creditworthiness with and without external support. We find that the size of the funding advantage is large and fluctuates substantially over time. For most countries it rises from $0.1 \%$ of GDP in the first half of 2008 to more than 1\% of GDP mid 2011. Our results are comparable to findings in previous studies. We find that larger banks enjoy on average higher rating uplifts, but the effect of size does not increase anymore for banks with total assets above 1,000 billion Euro compared to banks with assets between 250 and 1,000 billion Euro. In addition, a higher sovereign rating of a bank's home country leads on average to a higher rating uplift for that bank.
\end{abstract}

JEL codes: G01, G21, G24 


\section{Introduction}

The recent financial crisis showed that policy makers are willing to bail-out large or otherwise important banks in order to prevent failure. This practice of protecting creditors of certain banks from losses in the event of failure because of the unacceptably large collateral damage to the financial system and the real economy of such a failure is referred to as "too-big-to-fail" (TBTF) or "too-systemically important to fail" policy.

It causes three types of distortion (Noss and Sowerbutts, 2012). First, TBTF banks have lower funding costs since their creditors are protected by the government. This gives such banks a competitive edge over other banks, providing an incentive to become inefficiently large. Second, the implicit subsidy increases the banks' incentives to take risk because the market discipline by investors decreases. This distorts investment decisions and makes banks too risky. Third, because lower funding costs partly accrue to banks' clients, financial services are too cheap and more of them are produced and consumed than would be the case in absence of such a subsidy.

We build on the work by Noss and Sowerbutts (2012) and Schich and Lindh (2012) and determine the funding advantage for a sample of 151 large European banks using Moody's assessment of banks' creditworthiness in the absence and presence of external support. In particular, using this assessment, this approach determines how interest rates paid by banks would rise in the absence of external support. We add to these previous studies in two ways. First, we collect individual bank's bond data. This allows us to estimate the relationship between funding costs and ratings more precisely using OLS. Second, we calculate the annual funding cost advantage on a daily basis.

We find that the size of the funding advantage is large, and fluctuates substantially over time. Moreover, we show that the rating uplift, and thus the funding advantage, is related to both bank and country characteristics. In general, rating uplifts are larger for banks 
above some threshold value of total assets and the rating uplift increases as the creditworthiness of the bank's home country rises.

The remainder of our paper is organized as follows. Section two provides an overview of the empirical literature on the measurement of implicit TBTF subsidies or funding advantages in the banking sector ${ }^{3}$. Section three discusses the funding costs advantage approach in more detail and explains how we implement this strategy to estimate the funding advantage for a sample of 151 European banks. Section four gives a description of the data and in section five we present our results. Finally, section six concludes.

\section{$2 \quad$ Literature}

We discuss the empirical evidence on the existence and quantification of the TBTF subsidy. The questions that the empirical literature tries to answer are (i) are creditors of large banks indeed protected by the government and (ii) if so, what is the magnitude of the distortions related to TBTF? These studies can be categorized into five widely employed empirical strategies: event studies, mergers and acquisitions, distortions of market prices, issuer ratings, and contingent claims models. Most of the studies discussed in this overview find evidence that support the existence of TBTF banks. Appendix A provides an overview of the literature discussed below.

\subsection{Event studies}

Event studies try to assess the impact of events that affect market beliefs concerning TBTF subsidies on market prices. These studies are relatively scarce, as it is difficult to identify events where the beliefs of the market on whether a particular bank is TBTF change. Although it may be possible to identify that market prices indeed changed, it is difficult to determine the extent to which markets already considered banks to be too-big-to-fail before a given event. These studies thus give a lower bound for the size of the effect.

\footnotetext{
${ }^{3}$ There is a difference between TBTF subsidies and funding advantages. In the funding costs advantage approach we apply, we do not calculate the flow of subsidy from the government to the TBTF banks. Using this approach we are only able to calculate the advantage enjoyed by banks resulting from the implicit government guarantee.
} 
O'Hara and Shaw (1990) used the announcement in September 1984 of the US Comptroller of the Currency stating that the eleven largest banks were considered as TBTF to compare equity prices before and after the announcement. The idea is that profits will increase as a result of lower funding costs for TBTF banks and that the increased profits accrue at least partly to the shareholders ${ }^{4}$. Note that customers and creditors of the bank may also capture some of the benefit. The authors find indeed a positive wealth effect accruing to TBTF banks. For covered banks they estimate a significant positive average residual return of about $1.3 \%$ on the day of the announcement $t^{5}$. The non-covered banks experienced on average negative, but not significant, abnormal returns.

Pop and Pop (2009) quantify the wealth effects accruing to both large and small Japanese banks after the Japanese government decided to bailout Resona Holdings on May 17th 2003. At that moment, Resona Holdings was the fifth largest financial group of the country. On the event day, significantly negative abnormal equity returns of on average $5.58 \%$ were found for the five largest banks ${ }^{6}$. Two trading days later, the government provided additional details about the bailout and clearly stated that the shareholders would not incur any losses. The second announcement resulted in significant positive abnormal equity returns of about $8.40 \%$ for the five largest banks.

\subsection{Mergers and Acquisitions}

A second empirical strategy to quantify the size of the TBTF subsidy is to investigate the event of mergers and acquisitions between banks. When two banks merge into one and as a consequence become too-big-to-fail they earn a premium as a result of becoming toobig-to-fail. This would be an incentive for banks to merge. For example, the observation that only mergers undertaken by the largest banks lead to an increase in stock market value suggests that TBTF plays a role in explaining mergers between banks (Stern and Feldman, 2004). However, efficiency gains or increased market power are possible

\footnotetext{
${ }^{4}$ Another, indirect, effect could be that the bank is provided an incentive to increase the risk of its operations since the cost of funding is no longer tied to riskiness. This also leads to higher expected returns.

${ }^{5}$ This positive effect is not as obvious as it seems. It is for instance possible that the market already believed that large banks were fully protected (in May 1984, four months before the announcement, the eighth largest bank was bailed out).

${ }^{6}$ An explanation for this initial negative effect can be that the shareholders feared a nationalization of the bank imposing losses on the shareholders. This is what happened in Japan in the past, e.g. in 1998 with Long-Term Credit Bank of Japan and Nippon Credit Bank.
} 
alternative explanations for mergers between banks. To correct for these effects, these studies add proxies of bank riskiness as controls. A second way to address this issue is by identifying mergers below and above a particular too-big-to-fail level. Of course, the problem here is to identify what constitutes a too-big-to-fail bank.

Two alternative methods related to mergers and acquisitions are employed in the literature to test the impact of TBTF. The first method studies the impact of mergers and acquisitions on bond returns or stock market values of banks (e.g. Penas and Unal, 2004). The second method looks at merger premiums. If TBTF indeed plays a role banks should be willing to pay higher merger premiums if they become TBTF as a result of the merger (e.g. Brewer and Jagtiani, 2009).

Kane (2000) investigates a sample of 12 giant US banks between 1991 and 1998 and finds that these banks gain shareholder value from becoming larger via M\&A activity. It shows only that in the banking megamergers of 1991-98, stockholders of large-bank acquirers have gained value when a deposit institution target is large and that acquirers gained more value when a deposit institution target was previously headquartered in the same state.

Penas and Unal (2004) consider the impact of merger announcements on monthly bond returns of both acquiring and target-banks. They consider 65 US bank merger cases and calculate risk- and maturity-adjusted returns. The risk- and maturity-adjusted return is defined as the difference between the monthly raw bond return and the return of an index with similar rating and maturity characteristics to the specific bond. The length of the event window is 25 months; 12 months before the merger announcement and 12 months after the merger announcement.

Both acquirer and target banks' bondholders gain positive and significant bond returns around the merger month. Cumulative adjusted returns are $5.5 \%$ over the eight-month period including the announcement month and the seven preceding months; target bank bondholders benefit the most (4.3\%) while acquiring bank bondholders experience a cumulative adjusted return of only $1.2 \%$ over that period. Moreover, the adjusted bond returns are related to the asset size attained in the merger. The highest returns are realized 
by bondholders of medium size banks ${ }^{7}$ that become (close to) TBTF after merging. The bondholders of mega-banks and small banks realize no significant returns. This can be explained by the fact that mega-banks are already TBTF, whereas small banks do not become TBTF as a result of the merger.

Penas and Unal also relate the event of merger to the credit spread of new debt issues of the acquiring banks. The credit spread is defined as the difference between the yield at issue and the yield of a US treasury security with the same maturity. The regression results show that medium size acquiring banks experience on average a decrease in credit spreads of about 15 basis points, while this effect is not present for mega-banks and smaller banks. This finding also provides evidence for TBTF.

Brewer and Jagtiani (2009) focus on merger premiums and test the hypothesis that banks are willing to pay higher premiums to become TBTF. The merger premium is defined as the dollar amount above the market price that is paid by the acquirer. For a total number of 406 US bank merger cases, the merger premium is related to different merger scenarios with respect to the prior and post TBTF status ${ }^{8}$ of the acquirer and the target. The results are in line with TBTF as it is found that banks are willing to pay higher premiums for acquisitions that make them TBTF. The total extra premium paid by the eight acquiring banks that became TBTF after merging is estimated to be about \$16 billion.

Besides that, the results show that banks that are already TBTF are not willing to pay as much as banks that became TBTF as a result of the merger. However, the amount that already TBTF banks pay does increase in the size of the target bank. Finally, when the merging banks are both TBTF, the acquirer is not willing to pay excess premiums to increase its asset size. In that scenario the merging premium is found to be related to the correlation between the returns of the merging banks. Premiums are lower when a target's returns are strongly correlated with the returns of the acquirer, showing that portfolio diversification might play a role in explaining mergers between mega-banks.

\footnotetext{
7 Medium size banks are defined as banks with asset size between $0.35 \%$ and $2 \%$ of industry assets. The after-merger asset size of the medium size banks is about $\$ 100$ billion on average.

8 Three different TBTF thresholds are used: $\$ 100$ billion book value of total assets, banks that are one of the 11 largest organizations in each year, and banks with \$20 million market capitalization.
} 
Benston, Hunter, and Wall (1995) also examine purchase premiums in bank mergers. In contrast to Brewer and Jagtiani (2009), they find no evidence for the hypothesis that acquirers bid more for target-banks that would lead them to become TBTF. Instead, they find evidence for the hypothesis that banks bid more for merger partners because banks want to diversify earnings.

\subsection{Distortions of market prices}

A third strategy to measure the size of the subsidy is to analyze the distortion of market prices caused by the TBTF policy. The idea behind this strategy is that these prices will reflect the implicit subsidy. For example, the government implicit bailout policy for particular banks will lower CDS spreads for these banks because their default probability decreases. Again, big banks' market prices may be different for other reasons. These studies therefore include controls for bank risk.

Pop and Pop (2009) look at CDS spreads in order to further investigate the effects of TBTF. A lower CDS spread implies a lower probability of default as anticipated by the market. ${ }^{9}$ In line with TBTF, the authors find evidence for a decrease in CDS spreads after the Japanese government's bailout announcement.

Völz and Wedow (2009) analyze a dataset containing monthly average CDS spreads of 91 banks from 24 countries during the period 2002-2007. They relate the CDS spreads to various size measures and include a set of control variables for risk and liquidity. The size of banks is measured relative to the size of the home country's GDP in order to capture the feasibility of public bailout. By doing so, it is possible to examine both the TBTF effect and the phenomenon of "too-big-to-rescue" (TBTR) or "too-big-to-save" (TBTS). The idea behind TBTR is that some banks have reached a size that makes public intervention difficult. The authors find evidence for both TBTF and TBTR. A public bailout is estimated to become less likely beyond a market capitalization of 10 percent relative to GDP. A 1 percent increase in size is estimated to reduce CDS spreads by about 2 basis points (evaluated at the average market capitalization relative to GDP of about 4 percent). One

\footnotetext{
${ }^{9}$ Or a higher recovery rate. The recovery rate, however, is usually set at roughly $40 \%$.
} 
potential problem with this strategy is that large banks are simply less risky because they have for instance better diversified portfolios ${ }^{10}$. This effect may be captured by the size variable instead of the TBTF effect. Völz and Wedow deal with this by including volatility of equity returns as a proxy for diversification and show that this does not influence their conclusions.

Schweikhard and Tsesmelidakis (2012) follow another approach and compare credit market estimates of default with equity market estimates of default for 498 US companies in the period 2003-2009 ${ }^{11}$. Creditors are protected by the TBTF policy, while the value of equity is not ensured. The authors find that during the crises stock-market-implied CDS prices for banks are significantly higher than market CDS prices. Moreover, the price differentials are positively related to size. These findings all lend support to the existence of TBTF. The magnitude of the support is estimated to be about USD 129 billion over the period 2007-2010.

Demirgüç-Kunt and Huizinga (2010) find evidence for a "too-big-to-save" (TBTS) effect. They relate CDS spreads and the market-to-book ratio to the size of banks and two publicfinance variables: public debt and fiscal balance. They find that the market-to-book ratio of systemically important banks is significantly higher in countries with more public debt. They explain this by arguing that these countries are not able to save their largest banks if this would become necessary. Moreover, they find that an improvement of the fiscal balance leads to a decrease in the CDS spread.

Kelly, Lustig, and van Nieuwerburgh (2011) look at pricing of out-of-the-money put options on large banks. Such options are suitable to look at systemic risk because they price the risk of tail events. The analysis shows that out-of-the-money put options on financial sector index are cheaper than put options on individual financial firms. The price difference is consistent with reduction in the average loss rate for shareholders during financial disasters from 55.7 to 37.2 percent of equity. The authors interpret the difference

\footnotetext{
${ }^{10}$ The empirical evidence on the portfolio risk of large banks is mixed. Boyd and Gertler (1993) show that large US banks tended to take greater risks in the period 1984-1991. Demsetz and Strahan (1997) find that large banks have better diversified portfolios, but that this does not reduce overall risk of large banks. The reduced risk from better diversification is offset by lower capital ratios and larger commercial and industrial loan portfolios (see page 5 , Völz and Wedow).

${ }^{11}$ CDS spreads are used to measure credit market estimates of default. Equity market estimates of default are generated by a structural credit risk model.
} 
in pricing as evidence for the existence of a collective bail-out guarantee by the government.

Gandhi and Lustig (2012) look at size anomalies in U.S. bank stock returns. They use a Fama-French five factor model to determine abnormal returns. They find differences in average risk-adjusted returns on size-sorted bank portfolios. All else equal, a 100\% increase in a bank's book value lowers its annual return by $2.45 \%$ per annum. They argue this results in an annual saving of $\$ 4.71$ billion per bank for the largest commercial banks.

Balasubramnian and Cyree (2011) look at default risk sensitivity of yield spreads on bankissued subordinated notes and debentures before, during, and after the LTCM crisis in 1998. They find that the too-big-to-fail (TBTF) discount on yield spreads is absent prior to the LTCM bailout, but the size discount doubles after the LTCM bailout, consistent with the yield spreads reflecting the market's perception that large banks will be bailed out in case of trouble, whether such banks are explicitly identified as TBTF or not. They argue that the FRB's intervention in the LTCM bailout signaled the return of implicit guarantees in spite of the Federal Deposit Insurance Corporation Improvement Act (FDICIA) of 1991.

\section{$2.4 \quad$ Issuer ratings}

The analysis of issuer ratings provides a further method to quantify the subsidy of governments to TBTF banks. An important issue with this methodology is that it relies upon the subjective ratings of rating agencies. We will discuss the drawbacks of this methodology in more detail in section 3.2 below.

Morgan and Stiroh (2005) relate bond spread to issuer ratings. They show that the relationship between bond spreads and issuer ratings is flatter for banks in the US that are considered to be TBTF. This indicates that TBTF expectations are present; i.e. the bond spread of a TBTF bank is less sensitive to a rating downgrade than the bond spread of a smaller bank. 
Rime (2005) examines the difference between issuer ratings and individual ratings of banks. ${ }^{12}$ Issuer ratings consider all factors influencing the capacity of the bank to repay its debt, including potential external support. Individual ratings only incorporate the intrinsic capacity of the bank to repay its debt. The sample includes all banks rated both by Moody's and by Fitch IBCA in 21 countries for the period 1999-2003. Issuer ratings are regressed on the individual rating and a set of variables measuring different types of external support including a proxy for the TBTF status of a bank. The estimation results confirm the existence of TBTF banks. The impact of bank size on issuer ratings is positive and significant. Moreover, the impact is larger for banks with low individual ratings. The effect of banks being "too-big-to-rescue" (TBTR) is tested as well, but no evidence is found confirming this hypothesis.. The relationship between bond spreads and issuer ratings estimated by Sironi (2004) is used to calculate the monetary value of the implicit TBTF guarantee. For large, financially weak banks the rating bonus corresponds to a 20 to 80 basis points reduction in bond spreads. For large banks with high intrinsic financial strength the reduction in bond spreads as a result of TBTF guarantees is estimated to be 10 to 20 basis points.

Noss and Sowerbutts (2012) use credit ratings to determine the total value of the implicit TBTF subsidy to four large banks in the UK. They subtract Moody's 'stand-alone' rating from the higher 'support' credit rating and calculate the average yearly rating uplift for the four UK banks. The rating uplift of a bank corresponds to a decrease in costs of funding ${ }^{13}$. The difference between the actual and the counterfactual costs of funding is multiplied by each bank's risk-sensitive liabilities to estimate the size of the implicit subsidy ${ }^{14}$. The estimates of the total subsidy to the four banks using this funding advantage model vary over time from about $€_{5}$ billion in 2007 to about $€_{125}$ billion in 2009.

Using the same methodology Schich and Lindh (2012) produce an estimate of the implicit subsidy for 17 European countries. They also find that the size of the implicit

\footnotetext{
${ }^{12}$ In an early explorative analysis, Soussa (2000) finds a difference of three credit notches between small and TBTF banks pointing towards a competitive advantage for TBTF banks.

${ }^{13}$ The decrease in funding costs is approximated by comparing average yields of the Bank of America Merrill Lynch Sterling Corporates Financials Index at different ratings.

${ }^{14}$ This implies that the estimated subsidy depends on three factors; (i) the rating uplift, (ii) the relationship between funding costs and ratings, and (iii) the composition of bank funding. Especially the relationship between funding costs and ratings shows large variation over the years 2007-2010 in the UK, which has a large impact on the estimated size of the subsidy.
} 
subsidy is considerable, with a lower bound varying from 1.0\% of GDP (Germany) to less than $0.1 \%$ of GDP (Belgium) in March 2012. Besides that, they focus on the creditworthiness of the guarantor. Using cross section data for 123 large European banks from 17 countries at two points in time (December 2010 and March 2012), they find evidence for the hypothesis that implicit guarantees are higher for banks located in countries with a better sovereign rating. In line with Rime (2005) they find that implicit guarantees are higher for banks that are financially weaker.

\subsection{Contingent claims models}

Contingent claims determine the implicit subsidy in an option pricing framework as the expected annual payment from the government to the subsidized banks needed to prevent their default (Noss and Sowerbutts, 2012). The implicit subsidy is modeled as a put option with the underlying total assets of banks as a stochastic variable. If total assets of all banks are above the threshold value when the option expires, the option is not exercised and the payoff is zero. In case the total assets are below the threshold, the option is exercised and the payoff is equal to the difference between the threshold and the total assets. The value of the subsidy is equal to the expected value of the payoff.

In order to estimate the size of the subsidy using contingent claims models the dynamics and distribution of future assets values needs to be modeled. Noss and Sowerbutts (2012) use two different methods; (i) the equity option-price approach, and (ii) the historical approach $^{15}$. The first method leads to an estimated subsidy of $€ 120$ billion to UK banks in $2010^{16}$, whereas the second method estimates the subsidy to be about $£_{30}$ billion (compared to an estimated $€ 40$ billion in 2010 using the funding advantage approach). Although there is huge variation in the estimated size of the subsidy depending on the methodology and the point in time, the authors conclude that they found evidence for a substantial transfer of resources from the government to the banking system.

\footnotetext{
${ }^{15}$ The equity option-price approach models the future distribution of banks' equity values based on the prices of equity options. The price of an option gives an estimate of the risk of failure as perceived by investors. The historical approach estimates the distribution of banks' future assets values based on historical prices of bank equity.

${ }^{16}$ Oxera (2011) also uses the option pricing methodology. They estimate the expected value of state support to be 8 basis points per $£ 1$ of assets. For the UK they put the annual value transfer from the state at approximately $f_{5.9}$ billion.
} 


\section{$3 \quad$ Methodology}

We apply the funding cost advantage methodology of Noss and Sowerbutts (2012) and Schich and Lindh (2012) to estimate funding advantage of large European banks. This methodology uses credit ratings with and without explicit and implicit external support to determine the funding advantage enjoyed by a particular bank.

\subsection{Funding Advantage}

Suppose that bank Z receives an AA rating with support (Moody's Long Term Deposit (LTD) rating) and a B+ rating without support (Moody's Bank Financial Strength (BFS) rating) ${ }^{17}$. The methodology we use assumes that the counterfactual interest rate paid by bank $\mathrm{Z}$ in the absence of support equals the interest paid by a bank that has received a $\mathrm{B}+$ rating including support. The funding advantage is defined as the difference between the two interest rates. The funding advantage approach is based on correlation between ratings and funding $\operatorname{costs}^{18}$. Such a correlation does indeed exist in practice. For instance, Sironi (2003) shows that credit ratings are a better predictor of bank funding costs than accounting variables such as leverage, return on assets, and non-performing loans. Nevertheless, this correlation is not perfect, implying there are other factors that may explain the differences in interest rates paid by banks.

We determine the relationship between bond yields of bank $i$ at day $t\left(y_{i t}\right)$ and the LTDrating $\left(L T D_{i t}\right)$ by estimating equation (1) using OLS (with robust standard errors):

$$
y_{i t}=\alpha+\beta L T D_{i t}+\varepsilon_{i}
$$

We run the regression in equation (1) for every day $t$ to allow the relationship between ratings and bond yields to change over time. Our sample period spans four and a half year, which amounts to running this simple linear regression about 1,160 times. We use the

\footnotetext{
${ }^{17}$ The LTD rating includes both explicit and implicit external support, although the support from deposit insurance programs is not included in the rating. The BFS rating reflects the intrinsic financial strength of the bank.

${ }^{18}$ Note that it does not require any causal relationship between ratings and interest rates.
} 
estimated coefficients $\hat{\alpha}$ and $\hat{\beta}$ to estimate the predicted yield $\hat{y}_{i t}^{r}$ for rating $r$. In order to take the uncertainty in our regressions into account we also obtain the variance of the prediction $\operatorname{VAR}\left(\hat{y}_{i t}^{r}\right)$ from our estimates. The yield reduction is then given by $\hat{y}_{i t}^{B F S}-$ $\hat{y}_{i t}^{L T D}$. The uncertainty in the funding advantage is denoted by $\operatorname{VAR}\left(\hat{y}_{i t}^{B F S}-\hat{y}_{i t}^{L T D}\right)=$ $\operatorname{VAR}\left(\hat{y}_{i t}^{B F S}\right)+\operatorname{VAR}\left(\hat{y}_{i t}^{L T D}\right)-2 \operatorname{cov}\left(\hat{y}_{i t}^{B F S}, \hat{y}_{i t}^{L T D}\right)$.

Finally, we translate our measure of the yield reduction into a number reflecting the value of the funding advantage of a bank. Therefore we require to identify the amount of debt funding over which the bank enjoys a funding advantage. Here, several approaches are possible. One can look at only issued debt or total wholesale funding. In principle, it is also necessary to correct for the maturity of a bank's debt structure, as the funding advantage may be different for different debt maturities. In this paper we only consider long-term debt funding. To be more precise, we use the Bankscope variable long-term funding to measure the amount of outstanding debt. This variable includes debt funding with a maturity of more than 1 year. Short-term debt (with a maturity of less than 1 year) is not included in this measure, since one could imagine that a TBTF bank does not enjoy a funding advantage over this type of debt compared to a small bank. The reason is that the probability of bank failure within such a short period is very low, independent of the TBTF status of the bank.

The funding advantage is calculated by multiplying the yield reduction by the amount of outstanding debt. In fact, this methodology gives us a daily estimate for the annual funding advantage a bank enjoys. We use the uncertainty in the yield reduction $\operatorname{VAR}\left(\hat{y}_{i t}^{B F S}-\hat{y}_{i t}^{L T D}\right)$ to construct a $95 \%$ confidence interval for the size of the funding advantage.

Finally, we want to explain why some banks get a higher rating uplift than other banks. We relate the rating uplift to country and bank specific characteristics using OLS. 


\subsection{Caveats}

The methodology is subject to several caveats. A first issue is how to distinguish economies of scale from TBTF subsidies. ${ }^{19}$ If larger banks are more efficient or better diversified than small banks, interest rates will go down for larger banks. This tends to overstate the funding advantage. Studies try to address this in different ways, by correcting for banks risk profile such as leverage, the percentage of non-performing loans, or the zscore. Another possibility is to use event studies in which the TBTF-status of a bank suddenly changes. In principle, using Moody's BFS-rating should correct for this.

A second issue is that the ratings methodology depends on a subjective assessment by rating agencies to infer the size of the implicit subsidy. Thus, it is in fact the rating agencies' assessment of the governments subsidy to banks. Besides that, the Bank Financial Strength (BFS) rating we use does not include parental support. This means that the uplift we measure includes both parental and government support resulting in an overestimate of the funding advantage. ${ }^{20}$

A third issue is that due to data limitations the methodology ignores factors that result in uncertainty about the size of the funding advantage. The reduction in interest rates may differ between short-term funding and long-term funding. The maturity structure of a banks' funding will therefore affect the results, since the yield reduction may be different for different maturities.

\section{$4 \quad$ Data}

We combine data from three sources: Moody's rating data, data on balance sheets from Bankscope, and data on bond returns from Datastream.

Our sample consists of 151 relatively large European banks. We made a ranking of banks per country based on total assets and then made per country a selection of large banks (in absolute size) for which ratings data from Moody's was available. Table 1 lists the countries

\footnotetext{
${ }^{19}$ Note, however, that the empirical literature finds relatively little evidence of economies of scale above 200 bn dollar.

${ }^{20}$ Schich and Lindh (2012) use Moody's adjusted stand alone credit rating as a measure for the intrinsic strength of the bank. For the 123 European banks in their sample, the average uplift using the adjusted stand alone credit rating is 1.8 notches in March 2012 , while the average uplift amounts to 2.2 notches when using Moody's BFS rating. The disadvantage of using the adjusted stand alone credit rating is that it is only available as of 2007 (or later for most banks).
} 
in our sample, the corresponding number of banks per country, and the names of the included banks. Subsidiary banks are excluded from the sample if they are located in the same country as the parent bank. Including these banks would overestimate the funding advantage.

\subsection{Ratings}

From Moody's website we construct a dataset containing the daily Long Term Deposits rating (LTD) and the Bank Financial Strength rating (BFS) for the 151 European banks in our sample over the period 2006 until July $2012^{21}$. The LTD rating measures a bank's ability to repay punctually its foreign and/or domestic currency deposit obligations and includes intrinsic financial strength, sovereign transfer risk (for foreign currency deposits), and both implicit and explicit external support elements, but does not take into account the benefit of deposit insurance schemes that make payments to depositors. The BFS rating removes systemic and regional support from the LTD rating and is linked to the standalone intrinsic strength of the bank ${ }^{22}$. We dropped about $0.8 \%$ of the observations for which the BFS rating was higher than the LTD rating.

Table 2 gives an overview of the rating scales and the correspondence between the LTD and BFS ratings provided by Moody's. Table 3 and Table 4 show the number of banks with a specific rating on January 1st of every year in our sample. From 2008 onwards, the BFS ratings of banks started to drop. With respect to the LTD rating, we observe that the number of banks with a high rating (Aa3 or higher) started to fall from 2009 onwards. Table 5 presents the yearly number of upgrades and downgrades of the LTD and BFS ratings. Most of the BFS downgrades take place in 2009, while most of the LTD downgrades take place in 2011. Note that the number of LTD upgrades is remarkably high in 2007.

\footnotetext{
${ }^{21}$ Besides that, Moody's gives information about the specific rating action that is taken; the rating can be upgraded or downgraded, "on watch" (the event states if there will be a possible upgrade or downgrade), "new" (first rating), "withdrawn" (Moody's stopped rating the bank), "reinstated" (Moody's starting to rate again after having withdrawn), and "confirm only" (current rating is confirmed).
}

${ }^{22}$ See http://www.moodys.com/researchdocumentcontentpage.aspx?docid=PBC_79004 for more details. 


\subsection{Bank characteristics}

For the 151 banks in our sample we obtain yearly Bankscope data on long-term funding (LTF) to construct a measure for the amount of debt a bank enjoys the funding advantage over. We also include total assets (TA) data in order to be able to relate the funding advantage to the size of the bank. Table 6 presents yearly average values and standard deviations for these two variables. Note that the number of observations is somewhat higher than for the ratings data. The explanation is that the bank ratings are summarized on January 1st of each year, while the Bankscope data is for an entire year. So if a bank starts to receive a rating somewhere during the year, that bank is not included in the table with ratings, while the bank will be represented in Table 6 .

\subsection{Bond yields}

We use bond data from Datastream to determine the relationship between deposit ratings and bond yields. We download daily bond yields of bonds issued by the banks in our sample. The bonds we select all have fixed, positive, and annual coupon payments. Besides that, all bonds have a maturity between one and five years. Finally, we exclude bonds that are somehow guaranteed, for instance by (local) governments, parent banks, or with some form of collateral coverage ${ }^{23}$. After this selection procedure, our sample of bonds includes 505 bonds on the average day. The bonds are issued by 81 different banks (recall that our total ratings sample includes 151 banks).

The results from the regressions in equation (1) are shown in Figure 1 which shows the estimated yields for ratings Aaa, Aaz, Baa1, and Baa3. Note that the estimated Baaz ratings is only available from July 2010 onwards. The reason is that before that date our sample did not include any bonds issued by banks with a LTD-rating of Baaz or lower ${ }^{24}$.

\footnotetext{
${ }^{23}$ We also excluded some individual bonds by hand, because the yields of these bonds changed very infrequently. Probably these bonds are not very liquid.

${ }^{24}$ A potential problem is that we do have BFS-ratings of Baaz (or lower) before July 2010 . Before July 2010 we cannot estimate the counterfactual yield for banks with a BFS-rating of Baaz (or lower). We solve this problem by attaching the estimated Baaz-yield to these banks, meaning that we underestimate the true funding advantage. After July 2010, our dataset becomes richer in a sense, meaning that the underestimation problem reduces. This could potentially lead to jumps in our estimated funding advantages on the first date for which we are able to estimate the Baaz-rating. We tested this visually and do not find evidence for jumps in the funding advantage at days when the dataset becomes richer.
} 
Figure 2 shows the development of the estimated coefficient $\hat{\beta}$ over time. This figure shows that the relationship between ratings and yields has become much stronger during our sample period. This seems to give an indication that the relationship between ratings and yields becomes stronger during a period of financial distress. In Figure 3, we show how the t-statistic of the coefficient $\hat{\beta}$ develops over time. We observe that the relationship between ratings and yields is significant on almost every day. Only in the beginning of the sample period, when the relationship between ratings and yields was not very strong, the coefficient $\hat{\beta}$ was not always significant. In Figure 4 , the development over time of the explanatory power of the regressions, as measured by the $R^{2}$, is presented. As the size and significance of $\hat{\beta}$ increase, the explanatory power of the regression increases as well.

\subsection{Country characteristics}

From Moody's website we constructed a dataset with sovereign ratings of the countries in our sample. Table 7 shows that country ratings were high and did hardly change in the period 2006-2009. From 2010 onwards country ratings started to fall, although the number of countries with an Aaa-rating remains relatively high.

We finally included GDP data from Eurostat in order to measure the size of the bank relative to the size of the home country's economy.

\section{$5 \quad$ Results}

In this section we present the estimates of the funding advantage enjoyed by banks resulting from the funding costs advantage approach. Furthermore, we show the results from the regressions in which we try to explain the rating uplift of a bank by country and bank specific characteristics. 


\subsection{Funding cost advantage approach}

There are three factors that influence the size of the funding advantage in the approach we apply: the rating uplift, the corresponding yield reduction, and the amount of debt the bank enjoys the advantage over.

Table 8 shows the development of the average rating uplift over time. In the years prior to the crisis the average bank in our sample enjoyed a rating uplift of about 1 or 2 notches. The average uplifted increased to 3.6 notches in 2010 and then started to fall again to 2.5 notches in 2012.

The relationship between credit ratings and funding costs is shown in Figure 1. Clearly, a higher LTD rating results in lower funding costs for the bank. The relationship between predicted yields, or funding costs, and the LTD rating of a bank fluctuates over time and becomes stronger during the sample period 2008-2012.

The average amount of funding the banks in our sample enjoy the advantage over is presented in Table 6. This amount does not fluctuate very much over time, or at least there is no clear trend over time, meaning that changes in the amount of funding cannot explain changes in the size of the funding advantage.

Finally, we combine the three components and calculate the total funding advantage enjoyed by the 151 banks in our sample. The evolution of the funding advantage is shown in Figure 5. From Figure 5 it is clear that the fluctuations in the funding advantage are large. This is mainly explained by the fact that the relationship between ratings and yields is becoming stronger over time. Next to that, average rating uplifts started to increase at the beginning of the (banking) crisis in 2008. Banks' BFS ratings were downgraded, while the LTD ratings remained high. In the course of the Euro sovereign debt crisis, LTD ratings started to fall as well resulting in lower rating uplifts and, consequently, lower funding advantages. These findings suggest that the credibility of a country plays a role as well in explaining the value of the funding advantage received by banks.

Figure 6 presents the funding advantage relative to GDP for a selection of countries. For Germany, France, United Kingdom, and the Netherlands, estimated funding advantages are in the range of $0 \%-1.5 \%$ of GDP over the period $2008-2012$. The trend is the same for all 
four countries. Funding advantages are low in the beginning of 2008 and start to increase at the start of the financial crisis. This is mainly explained by rising rating uplifts in combination with a stronger relationship between ratings and yields. The funding advantage peaks just below 1.5\% of GDP for France and Germany during 2011. For the Netherlands and the United Kingdom the peak is somewhat lower at $1 \%$ of GDP and $1.25 \%$ of GDP respectively. In all four countries the funding advantage of large banks declined during the first half of 2012.

When we take a closer look at the funding advantages of banks from Spain, Italy, and Portugal in Figure 7, we see that the advantages enjoyed by banks are relatively small in these countries. This can be explained by the smaller rating uplifts that the banks from these countries enjoy. The fact that rating uplifts are relatively small in these countries is likely to be related to lower sovereign creditworthiness. The banking sector in, for example, Spain is not necessarily smaller when compared to GDP than the banking sector in France and Germany. So this is unlikely to explain the results we find. In Ireland, funding advantages are relatively large compared to the other three countries. The funding advantage enjoyed by Irish banks is somewhat higher than the advantage enjoyed by French and German banks.

The confidence intervals drawn in Figure 5-Figure 7 provide upper and lower bounds for the estimated funding advantage. The confidence interval fluctuates over time, but fluctuations are not very strong. The upper and lower bounds are relatively close to average funding advantages in the different countries. For instance, the average funding advantage of Dutch banks is $0.4 \%$ of GDP over the sample period, while the lower and upper bound are $0.3 \%$ and $0.5 \%$ respectively. In Appendix D we provide an overview of how our findings compare to previous (comparable) studies.

Figure 8 and Figure 9 give an indication of the interrelatedness between the size of the funding advantage, the sovereign rating, and the bank financial strength. The figures indicate that banks with a high financial strength rating (BFS $>C$-) have the lowest funding advantages. The reason is that the benefits from receiving a high LTD rating are by definition lower in the approach we apply given that the BFS rating of the bank is already high. For banks with a low BFS rating there is potentially more to gain. Next, the figures 
show that banks located in a country with a high sovereign rating ( $>$ Aa2) potentially benefit the most from the implicit government guarantee.

\subsection{Regressions}

The rating uplift is one of the components that determines the size of the funding advantage. But why do some banks get a higher rating uplift than other banks? In order to answer this question, we estimate different specifications of equation (2).

$$
R U_{i t}=\alpha+\gamma_{t}+\beta_{1} X_{i t}+\varepsilon_{i t}
$$

In equation (2), we want to explain the average rating uplift of bank $i$ in year $t\left(R U_{i t}\right)$ from bank and country specific variables $X_{i t}$. We define the rating uplift $R U_{i t}$ as a relative measure $R U_{i t}=\frac{L T D_{i t}-B F S_{i t}}{21-B F S_{i t}}$. The relative uplift measure takes into account that the absolute uplift is constrained by the BFS rating. For instance, banks with a BFS rating of Acan only enjoy a maximum rating uplift of one notch.

The results of our estimates are presented in Table 9. In the first two specifications we include only one bank specific variable; a TBTF dummy variable which takes on the value one when the total assets of bank $i$ are above a certain threshold. We employ threshold values of EUR 75 billion and EUR 250 billion. The results show that the TBTF dummies have a positive and statistically significant impact on the relative rating uplift. The relative rating uplift of TBTF banks is on average about $13 \%$ higher than the rating uplift of small banks, independent of the threshold value we choose. The average rating uplift of the banks in our sample is $38.8 \%$.

In specification three and four we include the sovereign rating of bank $i$ 's home country (SR) as an extra explanatory variable and we also include an interaction term with the TBTF dummy to test whether the value of being TBTF depends on the rating of the home country. The sovereign rating of the home country has a positive and significant influence on the rating uplift. The rating uplift is higher in countries that have a higher creditworthiness according to Moody's. The coefficient on the TBTF dummy switches sign 
and becomes negative and significant. This would imply that banks with total assets above a certain threshold receive a lower rating uplift. However, we cannot interpret this coefficient on its own since we also included an interaction term between the TBTF dummy and the sovereign rating. The interaction term has a positive and significant effect on the rating uplift. This implies that banks located in countries with a high sovereign rating enjoy a positive rating uplift. To be more precise we find that in the third specification, with a threshold of EUR 75 billion, TBTF banks enjoy a positive rating uplift when they are located in countries with a sovereign rating of 14 (=Baa1) or higher. When we choose to set the threshold at 250 billion we find a positive effect when the sovereign rating of $17(=\mathrm{A} 1)$ or higher ${ }^{25}$. In the final two specifications we introduce multiple TBTF threshold values to allow variation in the magnitude of the TBTF effect depending on the absolute size of bank $i$. We include dummies for banks with total assets between EUR 75 and 250 billion, between EUR 250 and 1000 billion, and above EUR 1000 billion. In specification five we find the largest positive effect for banks with total assets above EUR 1000 billion, although the difference with the size class EUR 250-1000 billion is very small. In specification six we include the sovereign rating and interaction terms between the size class dummies and the sovereign rating. Again, the coefficients on the TBTF dummies switch signs and become negative and significant. The sovereign rating and the interaction terms have a positive and significant influence on the rating uplift. The results are very similar to the findings of specification four. For banks in the first size class (EUR 75-250 billion), the effect of being TBTF becomes positive when the sovereign rating is 14 (=Baa1) or higher. In the latter two size classes (EUR 250-1000 and above EUR 1000 billion) the effect of being TBTF is positive for sovereign ratings above 17 (=A1).

\section{Conclusion}

Using Moody's assessment of banks' creditworthiness in the absence and presence of external support, we determine the annual funding advantage for a sample of 151 large

\footnotetext{
${ }^{25}$ Note from Table 7 that almost all banks are located in countries with a sovereign rating of 14 (=Baa1) or higher.
} 
European banks on a daily basis. We add to previous studies in two ways. First, we collect individual bank's bond data. This allows us to estimate the relationship between ratings and funding costs more precisely using OLS. Second, we calculate the funding cost advantage on a daily basis.

We find that the size of the funding advantage is large and fluctuates substantially over time. For most countries it rises from $0.1 \%$ of GDP in the first half of 2008 to more than $1 \%$ of GDP mid 2011. The latter value is in line with results from other studies. Moreover, we show that the rating uplift, and thus the funding advantage, is related to both bank and country characteristics. In general, rating uplifts are larger for banks above some threshold value of total assets and the rating uplift increases as the creditworthiness of the bank's home country rises. We find that rating uplifts are larger for banks that are above totals assets threshold values of EUR 75 and 250 billion. The effect of size does not increase anymore for banks with total assets above 1,000 billion Euro compared to banks with assets between 250 and 1,000 billion Euro. Moreover, rating uplifts are higher for banks located in countries with a high sovereign rating. 


\section{References}

Balasubramnian, Bhanu, and Ken B. Cyree, (2011), "Market Discipline of Banks: Why are Yield Spreads on Bank-Issued Subordinated Notes and Debentures Not Sensitive to Bank Risks?," Journal of Banking \& Finance 35, 21-35.

Benston, G., W. Hunter, and L. Wall, 1995. Motivations for Bank mergers and acquisitions: enhancing the deposit insurance put option versus earnings diversification. Journal of Money, Credit, and Banking, Vol. 27, No. 3, pp. 777-788.

Boyd, J.H. and M. Gertler, 1993. U.S. Commercial Banking: Trends, Cycles, and Policy. In NBER Macroeconomics Annual 1993, ed. Blanchard, O.J. and Fischer, S. Cambridge and London: MIT Press, 319-368.

Brewer, E. and J. Jagtiani, 2009. How Much Did Banks Pay to Become Too-Big-to-Fail and to Become Systemically Important? Federal Reserve Bank of Philadelphia, Working Paper No. 09-34.

Demsetz, R.S. and P.E. Strahan, 1997. Diversification, Size, and Risk at Bank Holding Companies. Journal of Money, Credit, and Banking, Vol. 29, No. 3, pp. 300-313.

Hetzel, R., 1991. Too Big to Fail: Origins, Consequences, and Outlook. Federal Reserve Bank of Richmond Economic Review 77 (6), pp. 3-15.

Kane, E. J. (2000): "Incentives for Banking Megamergers: What Motives Might Regulators Infer From Event-Study Evidence?," Journal of Money, Credit and Banking, 32(3), 671-701.

Mishkin, F.S., 2006. How big a problem is Too Big to Fail? A review of Gary Stern and Ron Feldman's Too Big to Fail: The Hazards of Bank Bailouts. Journal of Economic Literature, Vol. XLIV, pp. 988-1004.

Morgan, D.P. and K.J. Stiroh, 2005. Too Big to Fail after all these years. Federal Reserve Bank of New York, Staff Report, No. 220.

Noss, J. and R. Sowerbutts, 2012. The implicit subsidy of banks. Bank of England, Financial Stability Paper No. 15.

O'Hara, M. and W. Shaw, 1990. Deposit Insurance and wealth effects: the value of being "Too Big To Fail". Journal of Finance, Vol. 45, pp. 1587-1600. 
Oxera (2011), 'Assessing State Support to the UK Banking Sector', prepared at the request of the Royal Bank of Scotland, March.

Penas, M.F. and H. Unal, 2004. Gains in Bank Mergers: Evidence from the Bond Markets. Journal of Financial Economics, vol. 74, pp. 149-179.

Pop, A. and D. Pop, 2009. Requiem for market discipline and the specter of TBTF in Japanese banking. The Quarterly Review of Economics and Finance, vol. 49, pp. 1429-1459.

Rime, B., 2005. Do 'Too Big To Fail' Expectations Boost Large Banks Issuer Ratings? Working Paper, Systemic Stability Section, Swiss National Bank.

Schich, S. and S. Lindh, 2012. Implicit Guarantees for Bank Debt: Where Do We Stand? OECD Journal: Financial Market Trends, vol. 2012 Issue 1.

Schweikhard, F. and Z. Tsesmelidakis, 2012. The Impact of Government Interventions on CDS and Equity Markets. Available at SSRN: http://ssrn.com/abstract=1573377.

Soussa, F., 2000. Financial stability and central banks, selected issues for financial safety nets and market discipline. Chapter Too Big to Fail: Moral Hazard and Unfair Competition? Centre for Central Banking Studies, pp. 5-31.

Sironi, A., 2003. Testing for Market Discipline in the European Banking Industry: Evidence from Subordinated Debt Issues. Journal of Money, Credit, and Banking, Vol. 35, No. 3, pp. 443472.

Stern, G.H. and R.J. Feldman, 2004. Too Big to Fail: The Hazards of Bank Bailouts. Washington, D.C.: Brooking Institution Press.

Ueda and Weder di Mauro, 2011

Völz, M. and M. Wedow, 2009. Does Banks' Size Distort Market Prices? Evidence for TooBig-to-Fail in the CDS Market. Discussion Paper, No. 06/2009, Deutsche Bundesbank. 


\section{Appendix A: literature overview}

\begin{tabular}{|c|c|c|c|c|}
\hline Study & Published & Method & Sample & Results / Size of Effect \\
\hline \multicolumn{5}{|l|}{ Event Studies } \\
\hline $\begin{array}{l}\text { O’Hara and Shaw } \\
\text { (1990) }\end{array}$ & $\begin{array}{l}\text { Journal of } \\
\text { Finance }\end{array}$ & $\begin{array}{l}\text { Effect on bank equity values of the } \\
\text { decision by the Comptroller of the } \\
\text { Currency in } 1984 \text { to provide total } \\
\text { deposit insurance for some banks } \\
\text { that were considered as being } \\
\text { TBTF. }\end{array}$ & $\begin{array}{l}64 \text { US banks, including } \\
11 \text { TBTF banks. }\end{array}$ & $\begin{array}{l}\text { Significant positive residual return of } 1.3 \% \text { on day of the } \\
\text { announcement. No significant effect for small banks. }\end{array}$ \\
\hline $\begin{array}{l}\text { Pop and Pop } \\
(2009)\end{array}$ & $\begin{array}{l}\text { The Quarterly } \\
\text { Review of } \\
\text { Economics and } \\
\text { Finance }\end{array}$ & $\begin{array}{l}\text { Effect on stock prices of five } \\
\text { largest Japanese banks as a result of } \\
\text { the bailout of Resona Holding, the } \\
\text { fifth largest financial group in } \\
\text { Japan, in } 2003 \text {. }\end{array}$ & $\begin{array}{l}93 \text { Japanese banks }(5 \\
\text { large and } 88 \text { small } \\
\text { banks). }\end{array}$ & $\begin{array}{l}\text { Negative abnormal returns of }-5.6 \% \text { on the event day. } \\
\text { Later the government announced that shareholders would } \\
\text { not incur any losses, resulting in positive abnormal } \\
\text { returns of } 8.4 \% \text {. No significant effect for small banks. }\end{array}$ \\
\hline \multicolumn{5}{|l|}{ Market Prices } \\
\hline $\begin{array}{l}\text { Völz and Wedow } \\
\text { (2011) }\end{array}$ & $\begin{array}{l}\text { Journal of } \\
\text { Empirical } \\
\text { Finance }\end{array}$ & $\begin{array}{l}\text { Relate CDS spreads to various size } \\
\text { measures, controlling for risk and } \\
\text { liquidity. }\end{array}$ & $\begin{array}{l}91 \text { banks from } 24 \\
\text { countries }(2002-2007) .\end{array}$ & $\begin{array}{l}\text { A } 1 \% \text { increase in the size/GDP ratio reduces the CDS } \\
\text { spread by about } 2 \text { basis points. }\end{array}$ \\
\hline $\begin{array}{l}\text { Schweikhard and } \\
\text { Tsesmelidakis } \\
(2012)\end{array}$ & Working Paper & $\begin{array}{l}\text { Investigate impact of government } \\
\text { guarantees on the pricing of default } \\
\text { risk in credit and stock markets. }\end{array}$ & $\begin{array}{l}498 \text { US companies } \\
(2002-2010) \text {. }\end{array}$ & $\begin{array}{l}\text { Magnitude of support USD } 129.2 \text { billion for the period } \\
\text { 2007-2010. }\end{array}$ \\
\hline $\begin{array}{l}\text { Demirgüç-Kunt } \\
\text { and Huizinga } \\
\text { (2010) }\end{array}$ & Working Paper & $\begin{array}{l}\text { Relate market-to-book ration and } \\
\text { CDS spreads to bank size and } \\
\text { public finance variables. }\end{array}$ & $\begin{array}{l}59 \text { banks from } 20 \\
\text { countries. }\end{array}$ & Not clear \\
\hline $\begin{array}{l}\text { Barth and } \\
\text { Schnabel (2012) }\end{array}$ & Working Paper & $\begin{array}{l}\text { Relate CDS spreads to measure for } \\
\text { systemic risk, TBTS variable, and } \\
\text { interaction between TBTS and debt } \\
\text { ratio of the government. }\end{array}$ & & $\begin{array}{l}\text { No evidence for TBTF, but banks may be too systemic to } \\
\text { fail and TBTS. }\end{array}$ \\
\hline $\begin{array}{l}\text { Kelly, Lustig, and } \\
\text { Nieuwerburgh } \\
\text { (2011) }\end{array}$ & Working Paper & $\begin{array}{l}\text { Pricing of out-of-the-money put } \\
\text { options on large banks }\end{array}$ & $\begin{array}{l}\text { Index option prices on } \\
\text { the nine SPDR sector } \\
\text { exchange-traded funds } \\
\text { (ETFs) and on the } \\
\text { S\&P500 ETF }\end{array}$ & $\begin{array}{l}\text { Put options on sector index cheaper than put options on } \\
\text { individual financial firms. Consistent with reduction in } \\
\text { the average loss rate for shareholders during financial } \\
\text { disasters from } 55.7 \text { to } 37.2 \text { percent of equity. They } \\
\text { present this as the presence of a systemic bail-out }\end{array}$ \\
\hline Gandhi and Lustig & to be published & Size Anomalies in U.S. Bank Stock & 630 listed US banks & An annual saving of $\$ 4.71$ bn per bank for the largest \\
\hline
\end{tabular}




\begin{tabular}{|c|c|c|c|c|}
\hline (2012) & $\begin{array}{l}\text { in Journal of } \\
\text { Finance }\end{array}$ & $\begin{array}{l}\text { Returns using Fama-French five } \\
\text { factor model }\end{array}$ & & commercial banks. \\
\hline Sironi (2003) & $\begin{array}{l}\text { Journal of } \\
\text { Money, Credit } \\
\text { and Banking. }\end{array}$ & $\begin{array}{l}\text { The risk sensitivity of European } \\
\text { banks' subordinated notes and } \\
\text { debentures (SND) spread to } \\
\text { Moody's Bank Financial Strength } \\
\text { (MBFS) and FitchIBCA Individual } \\
\text { (FII) ratings }\end{array}$ & $\begin{array}{l}290 \text { fixed rate, non- } \\
\text { callable, non- } \\
\text { convertible, non- } \\
\text { perpetual SNDs from } \\
\text { Europeaqn banks in } \\
(1991-2000) \text { period. }\end{array}$ & $\begin{array}{l}\text { The sensitivity of SND spreads to measures of stand- } \\
\text { alone risk has been increasing from the first to the second } \\
\text { part of the 1990s. The claim is that private investors' } \\
\text { perception of too-big-to-fail type was gradually } \\
\text { disappearing }\end{array}$ \\
\hline $\begin{array}{l}\text { Anginer and } \\
\text { Warburton (2011) }\end{array}$ & Working Paper & $\begin{array}{l}\text { Credit spreads on bonds (difference } \\
\text { between yield and maturiy matched } \\
\text { treasury bond) issued by large U.S. } \\
\text { financial institutions }\end{array}$ & $\begin{array}{l}232 \text { U.S. financial } \\
\text { institutions (1980-2010) }\end{array}$ & $\begin{array}{l}\text { The implicit subsidy resulted in an annual funding cost } \\
\text { advantage of approximately } 16 \text { basis points (total value of } \\
\text { about } \$ 4 \text { billion) from } 1990-2007 \text {, increasing to } 88 \text { basis } \\
\text { points in the period } 2008-2010 \text { ( } \$ 60 \text { billion), peaking at } \\
\text { more than } 100 \text { basis points in } 2008 \text { ( } \$ 84 \text { billion). }\end{array}$ \\
\hline $\begin{array}{l}\text { Balasubramnian } \\
\text { and Cyree (2011) }\end{array}$ & $\begin{array}{l}\text { Journal of } \\
\text { Banking and } \\
\text { Finance }\end{array}$ & $\begin{array}{l}\text { They look at default risk sensitivity } \\
\text { of yield spreads on bank-issued } \\
\text { subordinated notes and debentures } \\
\text { before, during, and after the LTCM } \\
\text { crisis. }\end{array}$ & $\begin{array}{l}\text { Bond transaction data } \\
\text { for the years 1994- } \\
1999 .\end{array}$ & $\begin{array}{l}\text { The too-big-to-fail (TBTF) discount on yield spreads is } \\
\text { absent prior to the LTCM bailout, but the size discount } \\
\text { doubles after the LTCM bailout, consistent with the } \\
\text { argument that yield spreads reflect the bond market's } \\
\text { perception that if there is trouble, then all large banks will } \\
\text { be bailed out, whether such banks are explicitly identified } \\
\text { as TBTF or not. }\end{array}$ \\
\hline \multicolumn{5}{|l|}{$\begin{array}{l}\text { Mergers and } \\
\text { Acquisitions }\end{array}$} \\
\hline $\begin{array}{l}\text { Penas and Unal } \\
(2004)\end{array}$ & $\begin{array}{l}\text { Journal of } \\
\text { Financial } \\
\text { Economics }\end{array}$ & $\begin{array}{l}\text { Investigate the impact of merger } \\
\text { announcements on monthly bond } \\
\text { returns of acquiring and target } \\
\text { banks. }\end{array}$ & $\begin{array}{l}66 \text { US bank merger } \\
\text { cases (1991-1997). }\end{array}$ & $\begin{array}{l}\text { Positive cumulative adjusted bond returns of } 5.5 \% \text { around } \\
\text { the merger month for both acquirer and target banks' } \\
\text { bondholders. }\end{array}$ \\
\hline $\begin{array}{l}\text { Brewer and } \\
\text { Jagtiani (2011) }\end{array}$ & $\begin{array}{l}\text { Journal of } \\
\text { Financial } \\
\text { Services } \\
\text { Research }\end{array}$ & $\begin{array}{l}\text { Test the hypothesis that banks are } \\
\text { willing to pay higher merger } \\
\text { premiums to become TBTF. }\end{array}$ & $\begin{array}{l}406 \text { US bank merger } \\
\text { cases, } 8 \text { banks became } \\
\text { TBTF after merger } \\
(1991-2004) .\end{array}$ & $\begin{array}{l}\text { Banks are willing to pay higher premiums for acquisitions } \\
\text { that make them TBTF. The total extra premium paid by } \\
\text { the banks becoming TBTF is estimated to be USD } 16 \\
\text { billion. }\end{array}$ \\
\hline $\begin{array}{l}\text { Benston, Hunter } \\
\text { and Wall (1995) }\end{array}$ & $\begin{array}{l}\text { Journal of } \\
\text { Money, Credit } \\
\text { and Banking }\end{array}$ & $\begin{array}{l}\text { Test the hypothesis that banks are } \\
\text { willing to pay higher merger } \\
\text { premiums to become TBTF. }\end{array}$ & $\begin{array}{l}302 \text { US bank merger } \\
\text { cases (1981-1986). }\end{array}$ & $\begin{array}{l}\text { Empirical results consistent with earnings diversification } \\
\text { hypothesis and inconsistent with TBTF hypothesis. }\end{array}$ \\
\hline \multicolumn{5}{|l|}{ Issuer Ratings } \\
\hline Rime (2005) & $\begin{array}{l}\text { Swiss National } \\
\text { Bank, Working } \\
\text { Paper }\end{array}$ & $\begin{array}{l}\text { Examine the difference between } \\
\text { issuer ratings and individual ratings } \\
\text { of banks. }\end{array}$ & $\begin{array}{l}\text { All banks rated by } \\
\text { Moody's and Fitch in } 21 \\
\text { countries (1999-2003) }\end{array}$ & $\begin{array}{l}\text { For large, financially weak, banks the rating bonus } \\
\text { amounts to } 20-80 \text { basis points reduction in bond spread. } \\
\text { For large solid banks, this reduction is } 10-20 \text { basis points. }\end{array}$ \\
\hline
\end{tabular}




\begin{tabular}{|c|c|c|c|c|}
\hline $\begin{array}{l}\text { Noss and } \\
\text { Sowerbutts (2012) }\end{array}$ & $\begin{array}{l}\text { Bank of } \\
\text { England, } \\
\text { Financial } \\
\text { Stability Paper }\end{array}$ & $\begin{array}{l}\text { Examine the difference between } \\
\text { issuer ratings and individual ratings } \\
\text { of banks. }\end{array}$ & $\begin{array}{l}4 \text { major UK banks } \\
(2007-2010) .\end{array}$ & $\begin{array}{l}\text { The implicit subsidy varies between GBP } 5 \text { billion (in } \\
\text { 2007) and GBP } 130 \text { billion (in 2009). }\end{array}$ \\
\hline $\begin{array}{l}\text { Schich and Lindh } \\
\text { (2012) }\end{array}$ & $\begin{array}{l}\text { OECD } \\
\text { Journal: } \\
\text { Financial } \\
\text { Market Trends }\end{array}$ & $\begin{array}{l}\text { Examine the difference between } \\
\text { issuer ratings and individual ratings } \\
\text { of banks. }\end{array}$ & $\begin{array}{l}123 \text { large European } \\
\text { banks (2012) }\end{array}$ & $\begin{array}{l}\text { The lower bound of the implicit subsidy varies between } \\
0.1 \% \text { of GDP (for Belgium) and } 1.0 \% \text { of GDP (for } \\
\text { Germany). }\end{array}$ \\
\hline \multicolumn{5}{|l|}{$\begin{array}{l}\text { Contingent } \\
\text { Claims Models }\end{array}$} \\
\hline $\begin{array}{l}\text { Noss and } \\
\text { Sowerbutts (2012) }\end{array}$ & $\begin{array}{l}\text { Bank of } \\
\text { England, } \\
\text { Financial } \\
\text { Stability Paper }\end{array}$ & & & \\
\hline
\end{tabular}




\section{Appendix B: tables}

Table 1: sample

\begin{tabular}{|c|c|c|c|}
\hline Country & Number of Banks & Bank names & Period \\
\hline \multirow[t]{10}{*}{ Austria } & \multirow[t]{10}{*}{10} & BAWAG PSK Group & $2006-2012$ \\
\hline & & Erste Bank AG & $2007-2012$ \\
\hline & & Hypo Alpe Adria Group & $2007-2011$ \\
\hline & & Kommunalkredit Austria AG & $2009-2012$ \\
\hline & & Österreichische Volksbanken AG & $2006-2012$ \\
\hline & & Raiffeisen Bank International AG & 2010-2012 \\
\hline & & Raiffeisen Zentralbank Österreich AG & $2006-2010$ \\
\hline & & Raiffeisenlandesbank Nö-Wien AG & $2008-2012$ \\
\hline & & Raiffeisenlandesbank Oberösterreich AG & $2006-2012$ \\
\hline & & UniCredit Bank Austria & $2007-2012$ \\
\hline \multirow[t]{5}{*}{ Belgium } & \multirow[t]{5}{*}{5} & AXA Bank Europe SA/NV & $2011-2012$ \\
\hline & & Bank of New York Mellon SA/NV & $2009-2010$ \\
\hline & & Fortis Bank SA/NV - BNP Paribas Fortis & $2006-2012$ \\
\hline & & ING Belgium SA/NV & 2006-2012 \\
\hline & & KBC Group NV/KBC Groupe SA & 2006-2012 \\
\hline \multirow[t]{10}{*}{ Switzerland } & \multirow[t]{10}{*}{10} & Banque Cantonale Vaudoise & $2007-2012$ \\
\hline & & Clariden Leu AG & $2006-2010$ \\
\hline & & Credit Suisse AG & $2006-2012$ \\
\hline & & HSBC Private Bank (Suisse) SA & 2006-2012 \\
\hline & & Julius Baer Group Ltd & $2008-2012$ \\
\hline & & Raiffeisen Schweiz Genossenschaft & $2006-2012$ \\
\hline & & St. Galler Kantonalbank AG & $2006-2012$ \\
\hline & & UBS AG & 2006-2012 \\
\hline & & Valiant Holding & $2006-2012$ \\
\hline & & Zürcher Kantonalbank & 2006-2012 \\
\hline \multirow[t]{3}{*}{ Czech Republic } & \multirow[t]{3}{*}{3} & Ceska Sporitelna a.s. & $2006-2012$ \\
\hline & & CSOB & $2006-2012$ \\
\hline & & Komercni Banka & 2006-2012 \\
\hline \multirow[t]{12}{*}{ Germany } & \multirow[t]{12}{*}{12} & Bayerische Landesbank & $2006-2012$ \\
\hline & & Commerzbank AG & 2006-2012 \\
\hline & & DZ Bank AG & $2006-2012$ \\
\hline & & Deutsche Bank AG & 2006-2012 \\
\hline & & Deutsche Pfandbriefbank & $2006-2012$ \\
\hline & & Eurohypo AG & $2006-2007$ \\
\hline & & HSH Nordbank AG & $2006-2012$ \\
\hline & & Landesbank Baden-Wuerttemberg & $2006-2012$ \\
\hline & & Landesbank Hessen-Thueringen & $2006-2012$ \\
\hline & & Norddeutsche Landesbank & $2006-2012$ \\
\hline & & UniCredit Bank AG & $2006-2012$ \\
\hline & & WestLB AG & $2006-2012$ \\
\hline \multirow[t]{5}{*}{ Denmark } & \multirow[t]{5}{*}{5} & Danske Bank A/S & $2006-2012$ \\
\hline & & Jyske Bank A/S & $2006-2012$ \\
\hline & & Nordea Bank Denmark A/S & 2006-2012 \\
\hline & & Nykredit Bank A/S & $2007-2012$ \\
\hline & & Sydbank A/S & 2006-2012 \\
\hline Estonia & 1 & Swedbank As & $2008-2010$ \\
\hline Spain & 12 & Banco Bilbao Vizcaya Argentaria SA & $2006-2012$ \\
\hline
\end{tabular}




\begin{tabular}{|c|c|c|c|}
\hline & & Banco Popular Espanol SA & $2006-2012$ \\
\hline & & Banco Santander SA & $2006-2012$ \\
\hline & & Banco de Sabadell & $2006-2012$ \\
\hline & & Bankia SA & 2011-2012 \\
\hline & & Bankinter SA & $2006-2012$ \\
\hline & & Catalunya Caixa & 2010-2011 \\
\hline & & Novacaixa Galicia & 2010-2010 \\
\hline & & Caixabank & 2011-2012 \\
\hline & & Ibercaja & 2006-2011 \\
\hline & & La Caixa & 2006-2011 \\
\hline & & Liberbank SA & $2011-2012$ \\
\hline \multirow[t]{4}{*}{ Finland } & \multirow[t]{4}{*}{4} & Aktia Bank Plc & $2008-2012$ \\
\hline & & Nordea Bank Finland Plc & $2006-2012$ \\
\hline & & Pohjola Bank Plc & 2006-2012 \\
\hline & & Sampo Bank Plc & 2006-2012 \\
\hline \multirow[t]{7}{*}{ France } & \multirow[t]{7}{*}{7} & BNP Paribas & $2006-2012$ \\
\hline & & BPCE SA & 2006-2012 \\
\hline & & Banque Fédérative du Crédit Mutuel & $2006-2012$ \\
\hline & & Crédit Agricole SA & 2006-2012 \\
\hline & & Dexia Crédit Local SA & $2006-2012$ \\
\hline & & HSBC France & $2006-2012$ \\
\hline & & Société Générale & $2006-2012$ \\
\hline \multirow[t]{13}{*}{ United Kingdom } & \multirow[t]{13}{*}{13} & Bank of Ireland (UK) Plc & $2010-2012$ \\
\hline & & Barclays Bank Plc & $2006-2012$ \\
\hline & & Clydesdale Bank Plc & 2006-2012 \\
\hline & & Co-operative Bank Plc & $2006-2012$ \\
\hline & & Coventry Building Society & $2006-2012$ \\
\hline & & HSBC Bank Plc & $2006-2012$ \\
\hline & & Lloyds TSB Bank Plc & $2006-2012$ \\
\hline & & National Westminster Bank Plc & 2006-2012 \\
\hline & & Nationwide Building Society & $2006-2012$ \\
\hline & & Northern Rock (Asset Management) Plc & $2006-2010$ \\
\hline & & Santander UK Plc & $2006-2012$ \\
\hline & & Standard Chartered Bank & $2006-2012$ \\
\hline & & Yorkshire Building Society & $2006-2011$ \\
\hline \multirow[t]{7}{*}{ Greece } & \multirow[t]{7}{*}{7} & Agricultural Bank of Greece & $2006-2010$ \\
\hline & & Alpha Bank AE & $2006-2012$ \\
\hline & & EFG Eurobank Ergasias SA & $2006-2012$ \\
\hline & & Emporiki Bank of Greece SA & $2006-2012$ \\
\hline & & Marfin Egnatia Bank SA & $2006-2010$ \\
\hline & & National Bank of Greece SA & $2006-2012$ \\
\hline & & Piraeus Bank SA & 2006-2012 \\
\hline \multirow[t]{4}{*}{ Hungary } & \multirow[t]{4}{*}{4} & Erste Bank Hungary Nyrt & $2006-2010$ \\
\hline & & K\&H Bank Zrt & $2006-2010$ \\
\hline & & MKB Bank Zrt & 2006-2012 \\
\hline & & OTP Bank Plc & 2006-2011 \\
\hline \multirow[t]{7}{*}{ Ireland } & \multirow[t]{7}{*}{7} & Allied Irish Banks Plc & $2006-2012$ \\
\hline & & Bank of Ireland & $2006-2012$ \\
\hline & & DePfa ACS Bank & 2010-2012 \\
\hline & & DePfa Bank Plc & 2006-2012 \\
\hline & & Irish Bank Resolution Corporation & 2006-2012 \\
\hline & & Irish Life \& Permanent Plc & $2006-2012$ \\
\hline & & Ulster Bank Ireland Limited & 2006-2010 \\
\hline
\end{tabular}




\begin{tabular}{|c|c|c|c|}
\hline \multirow[t]{12}{*}{ Italy } & 12 & Banca Carige SpA & $2006-2012$ \\
\hline & & Banca Monte dei Paschi di Siena SpA & $2006-2012$ \\
\hline & & Banca Nazionale del Lavoro SpA & $2007-2012$ \\
\hline & & Banca Popolare di Milano SCaRL & 2006-2012 \\
\hline & & Banca Popolare & $2006-2012$ \\
\hline & & Cassa di Risparmio di Parma e Piacenza SpA & 2006-2012 \\
\hline & & Credito Emiliano SpA & 2010-2012 \\
\hline & & Credito Valtellinese Soc Coop & $2006-2012$ \\
\hline & & Dexia CREDIOP SpA & $2006-2012$ \\
\hline & & Intesa Sanpaolo & $2006-2012$ \\
\hline & & UniCredit SpA & $2006-2012$ \\
\hline & & Unione di Banche Italiane Scpa & 2006-2012 \\
\hline \multirow[t]{4}{*}{ Luxembourg } & 4 & BGL BNP Paribas & $2006-2012$ \\
\hline & & Banque et Caisse d'Epargne de l'Etat LU & $2007-2012$ \\
\hline & & Norddeutsche Landesbank Luxembourg SA & $2007-2012$ \\
\hline & & UniCredit Luxembourg SA & 2007-2012 \\
\hline \multirow[t]{7}{*}{ Netherlands } & 7 & Credit Europe Bank NV & $2006-2012$ \\
\hline & & ING Bank NV & $2006-2012$ \\
\hline & & Leaseplan Corporation NV & 2011-2012 \\
\hline & & NIBC Bank NV & $2006-2012$ \\
\hline & & Rabobank Nederland & $2006-2012$ \\
\hline & & Royal Bank of Scotland NV & $2007-2012$ \\
\hline & & SNS Bank NV & 2006-2012 \\
\hline \multirow[t]{5}{*}{ Norway } & 5 & DNB Bank ASA & $2006-2012$ \\
\hline & & Nordea Bank Norge ASA & $2006-2012$ \\
\hline & & Sparebank 1 SMN & $2006-2012$ \\
\hline & & Sparebank 1 SR - Bank & $2006-2012$ \\
\hline & & Sparebanken Vest & $2006-2012$ \\
\hline \multirow[t]{8}{*}{ Poland } & 8 & BRE Bank SA & $2006-2012$ \\
\hline & & Bank Millennium & $2006-2012$ \\
\hline & & Bank Polska Kasa Opieki SA - Bank Pekao SA & $2006-2012$ \\
\hline & & Bank Zachodni WBK SA & $2006-2012$ \\
\hline & & Getin Noble Bank SA & 2010-2012 \\
\hline & & ING Bank Slaski SA - Capital Group & $2006-2012$ \\
\hline & & Kredyt Bank SA & $2006-2009$ \\
\hline & & Powszechna Kasa Oszczednosci Bank Polski & 2006-2012 \\
\hline \multirow[t]{7}{*}{ Portugal } & 7 & BANIF SA & $2006-2012$ \\
\hline & & Banco BPI SA & $2006-2012$ \\
\hline & & Banco Comercial Português SA & 2006-2012 \\
\hline & & Banco Espirito Santo SA & $2006-2012$ \\
\hline & & Banco Santander Totta SA & $2006-2012$ \\
\hline & & Caixa Economica Montepio Geral & $2006-2010$ \\
\hline & & Caixa Geral de Depositos & 2006-2012 \\
\hline \multirow[t]{5}{*}{ Sweden } & 5 & Länsförsäkringar Bank AB (Publ) & $2006-2012$ \\
\hline & & Nordea Bank AB (Publ) & $2006-2012$ \\
\hline & & Skandinaviska Enskilda Banken AB & $2006-2012$ \\
\hline & & Svenska Handelsbanken & $2006-2010$ \\
\hline & & Swedbank AB & 2006-2012 \\
\hline Slovenia & 1 & NLB dd - Nova Ljubljanska Banka dd & 2006-2012 \\
\hline \multirow[t]{2}{*}{ Slovakia } & 2 & Slovenska Sporitel'na AS & $2006-2009$ \\
\hline & & Vseobecna Uverova Banka AS & 2006-2012 \\
\hline Total & 151 & & \\
\hline
\end{tabular}


Table 2: Moody's ratings scales

\begin{tabular}{lll}
\hline LTD rating & BFS rating & Numeric Value \\
\hline C & & 1 \\
Ca & & 2 \\
Caa3 & & 3 \\
Caa2 & E & 4 \\
Caa1 & & 5 \\
B3 & & 6 \\
B2 & E+ & 7 \\
B1 & & 8 \\
Ba3 & D- & 9 \\
Ba2 & D & 10 \\
& D+ & 11.5 \\
Ba1 & & 11 \\
Baa3 & & 12 \\
Baa2 & & 13 \\
& C- & 13.5 \\
Baa1 & & 14 \\
A3 & C & 15 \\
A2 & C+ & 16 \\
A1 & B- & 17 \\
Aa3 & B & 18 \\
Aa2 & B+ & 19 \\
Aa1 & A- & 20 \\
Aaa & A & 21 \\
\hline & &
\end{tabular}

Table 3: LTD ratings

\begin{tabular}{lrrrrrrr}
\hline LTD on January 1st & $\mathbf{2 0 0 6}$ & $\mathbf{2 0 0 7}$ & $\mathbf{2 0 0 8}$ & $\mathbf{2 0 0 9}$ & $\mathbf{2 0 1 0}$ & $\mathbf{2 0 1 1}$ & $\mathbf{2 0 1 2}$ \\
\hline Caa2 & 0 & 0 & 0 & 0 & 0 & 0 & 4 \\
Caa1 & 0 & 0 & 0 & 0 & 0 & 0 & 1 \\
B3 & 0 & 0 & 0 & 0 & 0 & 0 & 1 \\
B2 & 0 & 0 & 0 & 0 & 0 & 0 & 0 \\
B1 & 0 & 0 & 0 & 0 & 0 & 0 & 1 \\
Ba3 & 0 & 0 & 0 & 0 & 0 & 0 & 3 \\
Ba2 & 0 & 0 & 0 & 0 & 1 & 2 & 7 \\
Ba1 & 0 & 0 & 0 & 0 & 0 & 3 & 3 \\
Baa3 & 1 & 2 & 1 & 1 & 1 & 11 & 5 \\
Baa2 & 0 & 0 & 0 & 0 & 5 & 3 & 6 \\
Baa1 & 5 & 4 & 5 & 4 & 11 & 5 & 11 \\
A3 & 9 & 10 & 2 & 5 & 9 & 10 & 9 \\
A2 & 30 & 29 & 22 & 20 & 23 & 17 & 28 \\
A1 & 23 & 24 & 19 & 21 & 33 & 29 & 21 \\
Aa3 & 25 & 31 & 28 & 33 & 27 & 25 & 18 \\
Aa2 & 15 & 16 & 23 & 22 & 18 & 15 & 6 \\
Aa1 & 7 & 8 & 28 & 23 & 6 & 4 & 2 \\
Aaa & 2 & 3 & 6 & 4 & 3 & 3 & 3 \\
\hline Total & $\mathbf{1 1 7}$ & $\mathbf{1 2 7}$ & $\mathbf{1 3 4}$ & $\mathbf{1 3 3}$ & $\mathbf{1 3 7}$ & $\mathbf{1 2 7}$ & $\mathbf{1 2 9}$ \\
\hline
\end{tabular}


Table 4: BFS ratings

\begin{tabular}{lrrrrrrr}
\hline BFS on January 1st & $\mathbf{2 0 0 6}$ & $\mathbf{2 0 0 7}$ & $\mathbf{2 0 0 8}$ & $\mathbf{2 0 0 9}$ & $\mathbf{2 0 1 0}$ & $\mathbf{2 0 1 1}$ & $\mathbf{2 0 1 2}$ \\
\hline E & 0 & 0 & 0 & 0 & 3 & 2 & 6 \\
E+ & 0 & 1 & 2 & 4 & 7 & 9 & 12 \\
D- & 5 & 4 & 1 & 1 & 5 & 5 & 6 \\
D & 1 & 1 & 5 & 5 & 14 & 11 & 9 \\
D+ & 8 & 9 & 4 & 5 & 11 & 13 & 14 \\
C- & 11 & 11 & 21 & 24 & 45 & 43 & 38 \\
C & 15 & 17 & 23 & 27 & 21 & 17 & 24 \\
C+ & 16 & 20 & 31 & 27 & 16 & 15 & 12 \\
B- & 21 & 20 & 21 & 21 & 9 & 9 & 5 \\
B & 23 & 27 & 19 & 17 & 4 & 2 & 2 \\
B+ & 10 & 10 & 7 & 2 & 2 & 1 & 1 \\
A- & 5 & 5 & 0 & 0 & 0 & 0 & 0 \\
A & 2 & 2 & 0 & 0 & 0 & 0 & 0 \\
\hline Total & $\mathbf{1 1 7}$ & $\mathbf{1 2 7}$ & $\mathbf{1 3 4}$ & $\mathbf{1 3 3}$ & $\mathbf{1 3 7}$ & $\mathbf{1 2 7}$ & $\mathbf{1 2 9}$ \\
\hline
\end{tabular}

Table 5: rating events

\begin{tabular}{rrrrrrrr}
\hline & $\mathbf{2 0 0 6}$ & $\mathbf{2 0 0 7}$ & $\mathbf{2 0 0 8}$ & $\mathbf{2 0 0 9}$ & $\mathbf{2 0 1 0}$ & $\mathbf{2 0 1 1}$ & $\mathbf{2 0 1 2}$ \\
\hline downgrades LTD & 1 & 28 & 23 & 93 & 50 & 102 & 55 \\
upgrades LTD & 4 & 82 & 1 & 1 & 1 & 1 & 0 \\
downgrades BFS & 6 & 62 & 29 & 104 & 24 & 42 & 42 \\
upgrades BFS & 7 & 18 & 0 & 1 & 5 & 8 & 0 \\
\hline
\end{tabular}

Table 6: bank characteristics

\begin{tabular}{lrrrrrrr}
\hline & $\mathbf{2 0 0 6}$ & $\mathbf{2 0 0 7}$ & $\mathbf{2 0 0 8}$ & $\mathbf{2 0 0 9}$ & $\mathbf{2 0 1 0}$ & $\mathbf{2 0 1 1}$ & \multicolumn{1}{c}{ 2012 $^{*}$} \\
\hline TA & 213,557 & 228,546 & 239,303 & 220,457 & 227,324 & 247,180 & 254,711 \\
& $(333,844)$ & $(366,925)$ & $(408,846)$ & $(347,568)$ & $(375,293)$ & $(404,384)$ & $(411,742)$ \\
LTF & 43,352 & 42,947 & 41,715 & 40,706 & 36,195 & 36,838 & 37,815 \\
& $(70,974)$ & $(69,783)$ & $(79,309)$ & $(71,544)$ & $(54,144)$ & $(52,161)$ & $(52,998)$ \\
\hline$N^{* *}$ & $\mathbf{1 2 1}$ & $\mathbf{1 3 1}$ & $\mathbf{1 3 5}$ & $\mathbf{1 3 7}$ & $\mathbf{1 4 2}$ & $\mathbf{1 3 5}$ & $\mathbf{1 2 9}$ \\
\hline *we take values of 2011 as a proxy for 2012. Standard deviations in parentheses. \\
**the long-term funding data is missing for two small banks in some of the years
\end{tabular}


Table 7: sovereign ratings of the countries in our sample

\begin{tabular}{lccccccc}
\hline SR on January 1St & $\mathbf{2 0 0 6}$ & $\mathbf{2 0 0 7}$ & $\mathbf{2 0 0 8}$ & $\mathbf{2 0 0 9}$ & $\mathbf{2 0 1 0}$ & $\mathbf{2 0 1 1}$ & $\mathbf{2 0 1 2}$ \\
\hline Ca & 0 & 0 & 0 & 0 & 0 & 0 & 1 \\
Ba2 & 0 & 0 & 0 & 0 & 0 & 0 & 1 \\
Ba1 & 0 & 0 & 0 & 0 & 0 & 1 & 2 \\
Baa3 & 0 & 0 & 0 & 0 & 0 & 1 & 0 \\
Baa1 & 0 & 0 & 0 & 0 & 1 & 1 & 0 \\
A3 & 0 & 0 & 0 & 1 & 0 & 0 & 0 \\
A2 & 2 & 2 & 2 & 1 & 2 & 1 & 2 \\
A1 & 3 & 3 & 4 & 4 & 3 & 3 & 4 \\
Aa3 & 1 & 0 & 0 & 0 & 0 & 0 & 1 \\
Aa2 & 2 & 3 & 3 & 3 & 3 & 2 & 0 \\
Aa1 & 1 & 1 & 1 & 1 & 2 & 2 & 0 \\
Aaa & 13 & 13 & 13 & 13 & 12 & 11 & 11 \\
\hline Total & $\mathbf{2 2}$ & $\mathbf{2 2}$ & $\mathbf{2 3}$ & $\mathbf{2 3}$ & $\mathbf{2 3}$ & $\mathbf{2 2}$ & $\mathbf{2 2}$ \\
\hline
\end{tabular}

Table 8: average, minimum, and maximum uplift

\begin{tabular}{lccccccc}
\hline & $\mathbf{2 0 0 6}$ & $\mathbf{2 0 0 7}$ & $\mathbf{2 0 0 8}$ & $\mathbf{2 0 0 9}$ & $\mathbf{2 0 1 0}$ & $\mathbf{2 0 1 1}$ & $\mathbf{2 0 1 2}$ \\
\hline Average Uplift & 1.1 & 2.2 & 2.6 & 3.3 & 3.6 & 2.9 & 2.5 \\
Minimum & 0.0 & 0.0 & 0.0 & 0.0 & 0.0 & 0.0 & 0.0 \\
Maximum & 8.0 & 8.1 & 9.3 & 11.3 & 12.0 & 8.0 & 9.9 \\
\hline $\boldsymbol{N}$ & $\mathbf{1 2 1}$ & $\mathbf{1 3 1}$ & $\mathbf{1 3 5}$ & $\mathbf{1 3 7}$ & $\mathbf{1 4 2}$ & $\mathbf{1 3 5}$ & $\mathbf{1 2 9}$ \\
\hline
\end{tabular}


Table 9: OLS results

\begin{tabular}{|c|c|c|c|c|c|c|}
\hline & (1) & $(2)$ & (3) & (4) & (5) & (6) \\
\hline dep. variable & $R U_{i t}$ & $R U_{i t}$ & $R U_{i t}$ & $R U_{i t}$ & $R U_{i t}$ & $R U_{i t}$ \\
\hline \multirow[t]{2}{*}{ TBTF1 (75 billion) } & $13.35^{* * *}$ & & $-25.46^{* * *}$ & & & \\
\hline & $(10.34)$ & & $(-4.37)$ & & & \\
\hline \multirow[t]{2}{*}{ TBTF2 (250 billion) } & & $12.35^{* * *}$ & & $-40.08 * * *$ & & \\
\hline & & $(8.36)$ & & $(-3.54)$ & & \\
\hline \multirow[t]{2}{*}{ TBTF3 (75-250 billion) } & & & & & $10.88 * * *$ & $-21.53^{* * *}$ \\
\hline & & & & & $(6.86)$ & $(-3.77)$ \\
\hline \multirow[t]{2}{*}{$\mathrm{TBTF}_{4}$ (250-1000 billion) } & & & & & $15.84^{* * *}$ & $-51.57^{* * *}$ \\
\hline & & & & & $(8.77)$ & $(-3.70)$ \\
\hline \multirow[t]{2}{*}{ TBTF5 (>1000 billion) } & & & & & $16.22^{* * *}$ & $-46.68^{* * *}$ \\
\hline & & & & & $(8.61)$ & $(-4.88)$ \\
\hline \multirow[t]{2}{*}{ SR } & & & $1.282^{* * *}$ & $1.994^{* * *}$ & & $1.285^{* * *}$ \\
\hline & & & $(5.34)$ & $(10.63)$ & & (5.33) \\
\hline \multirow[t]{2}{*}{ TBTF1 x SR } & & & $1.858^{* * *}$ & & & \\
\hline & & & $(5.85)$ & & & \\
\hline \multirow[t]{2}{*}{ TBTF2 x SR } & & & & $2.385^{* * *}$ & & \\
\hline & & & & $(4.13)$ & & \\
\hline \multirow[t]{2}{*}{ TBTF3 x SR } & & & & & & $1.623^{* * *}$ \\
\hline & & & & & & $(5.03)$ \\
\hline \multirow[t]{2}{*}{ TBTF4 $x$ SR } & & & & & & $3.166^{* * *}$ \\
\hline & & & & & & $(4.41)$ \\
\hline \multirow[t]{2}{*}{ TBTF5 $\times$ SR } & & & & & & $2.899^{* * *}$ \\
\hline & & & & & & $(5.67)$ \\
\hline \multirow[t]{2}{*}{ Constant } & $9.097^{* * *}$ & $12.47^{* * *}$ & $-16.08^{* *}$ & $-26.40^{* * *}$ & $9.098^{* * *}$ & $-16.14^{* *}$ \\
\hline & $(3.86)$ & $(5.74)$ & $(-3.05)$ & $(-5.93)$ & $(3.86)$ & $(-3.05)$ \\
\hline Year dummies & Yes & Yes & Yes & Yes & Yes & Yes \\
\hline $\mathbf{N}$ & 928 & 928 & 928 & 928 & 928 & 928 \\
\hline adj. R-sq & 0.277 & 0.245 & 0.345 & 0.309 & 0.281 & 0.344 \\
\hline
\end{tabular}




\section{Appendix C: figures}

Figure 1: yields for different LTD-ratings

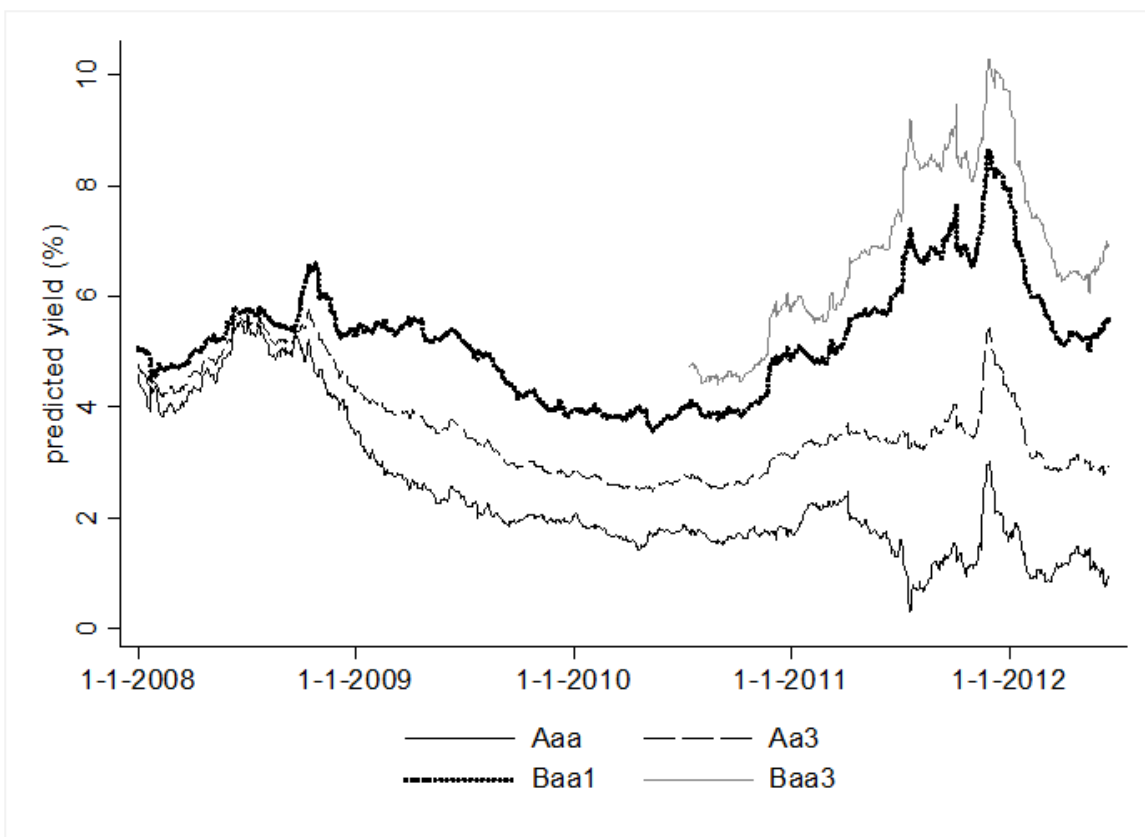

Figure 2: development over time of $\widehat{\boldsymbol{\beta}}$

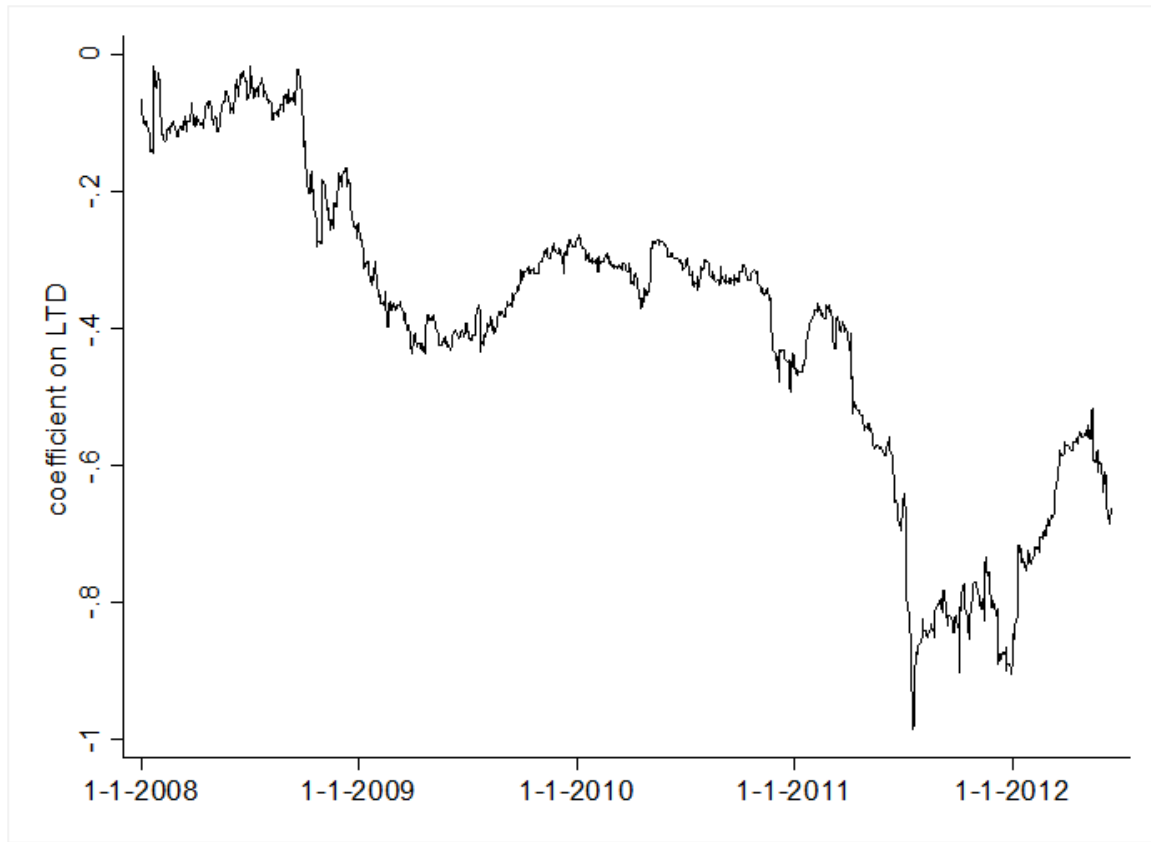


Figure 3: development over time of the t-statistic of $\widehat{\beta}$

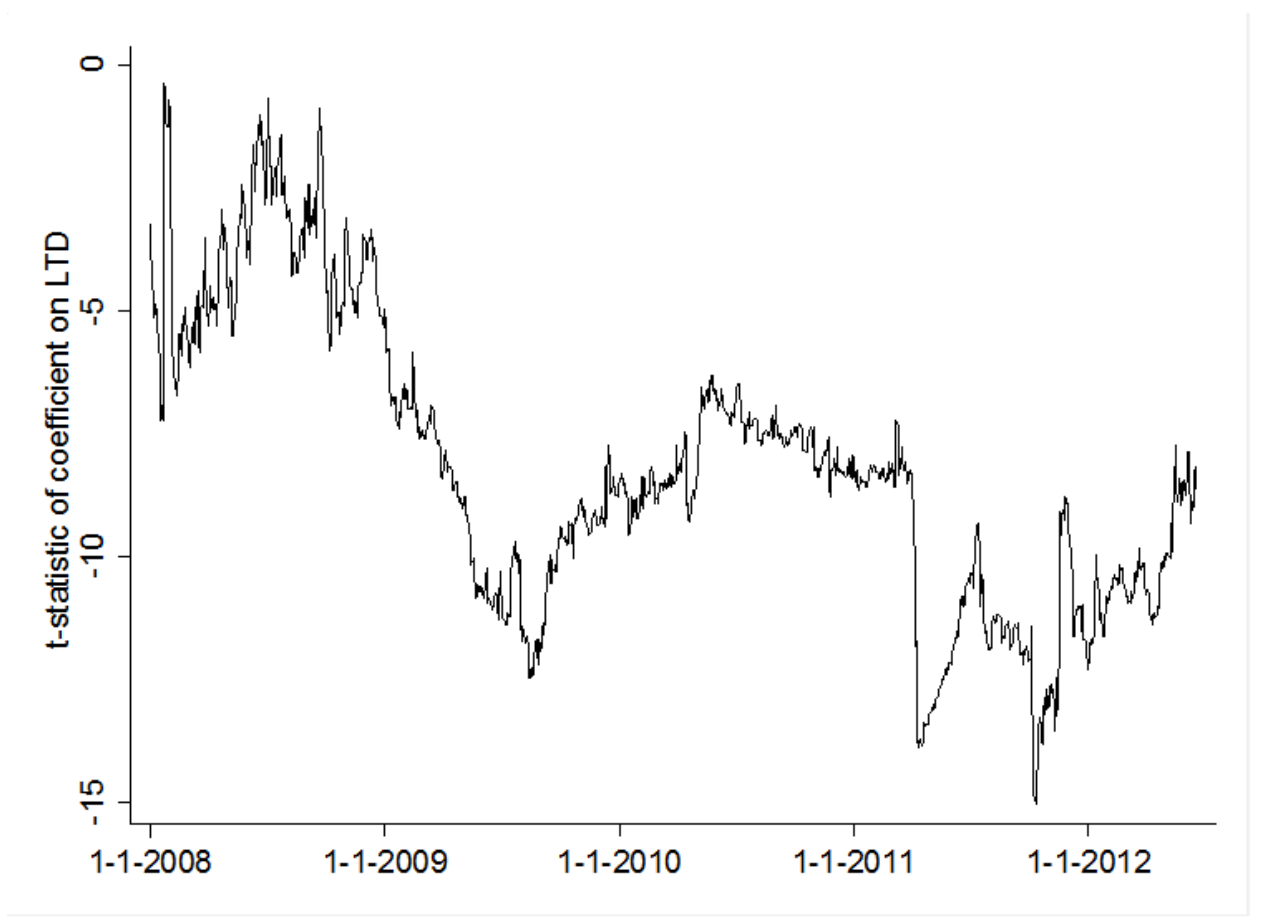

Figure 4: development over time of R-squared

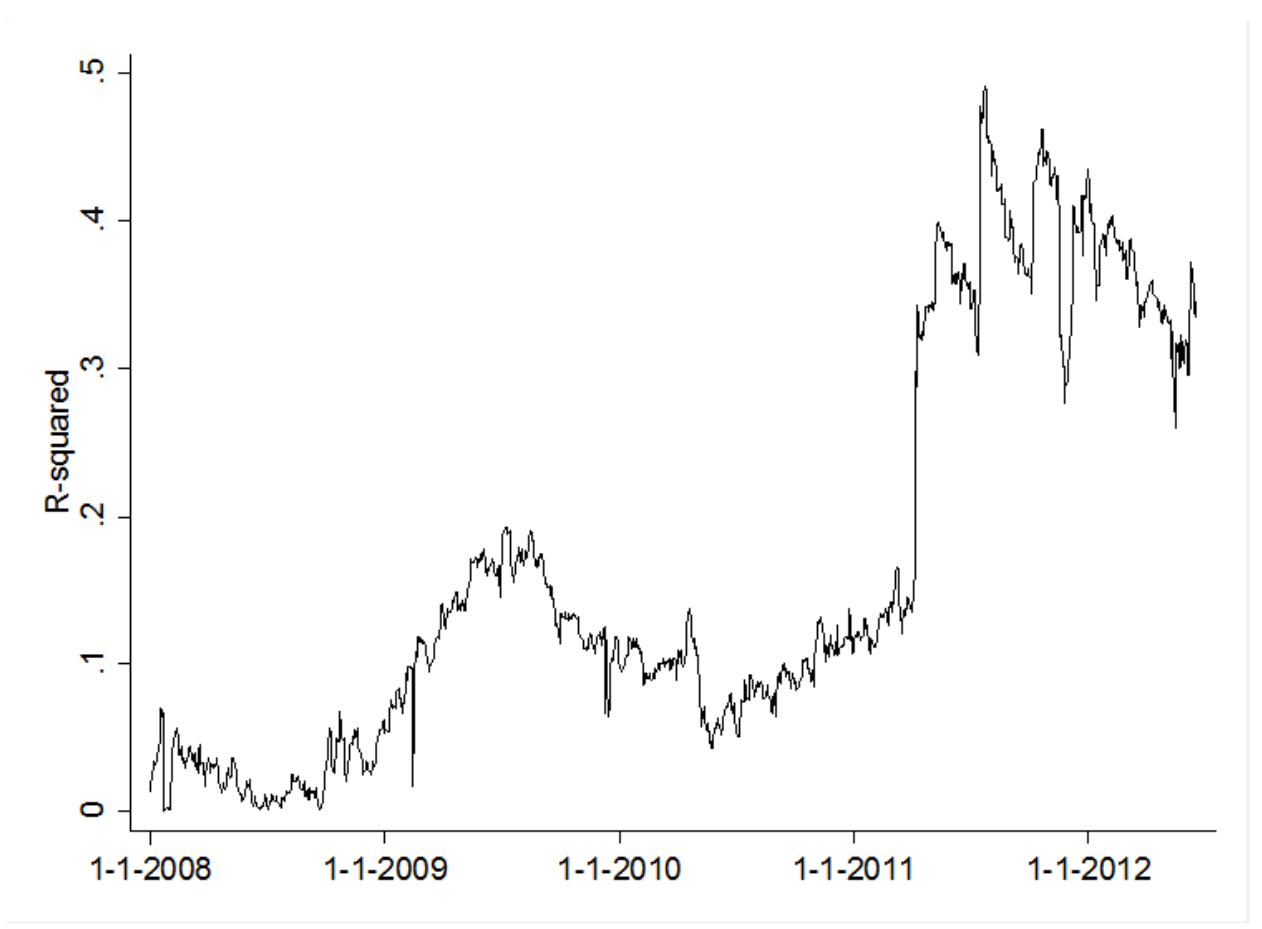


Figure 5: the total funding advantage and uncertainty area (in EUR billion)

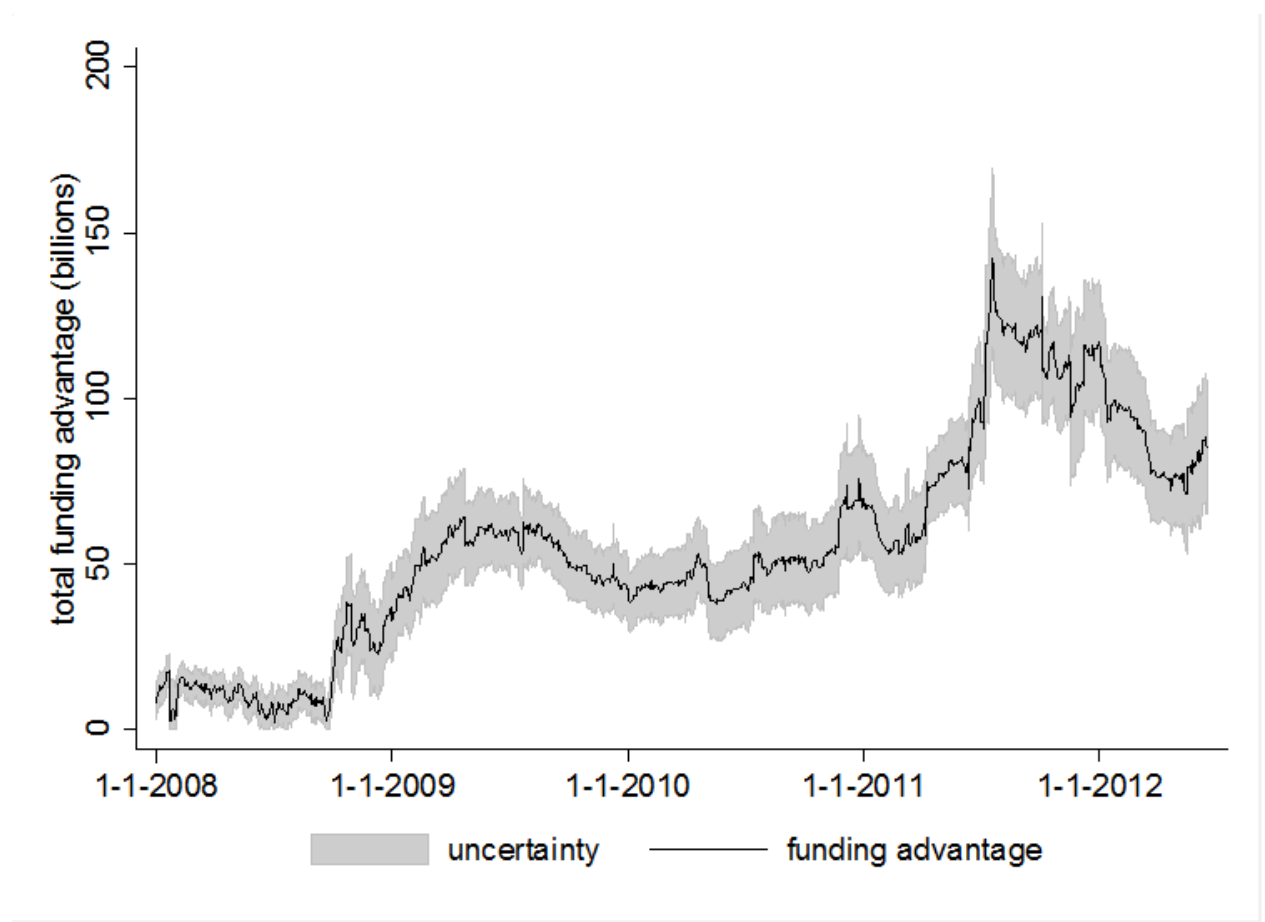

Figure 6: funding advantage per country (Germany, France, The Netherlands, and United Kingdom)
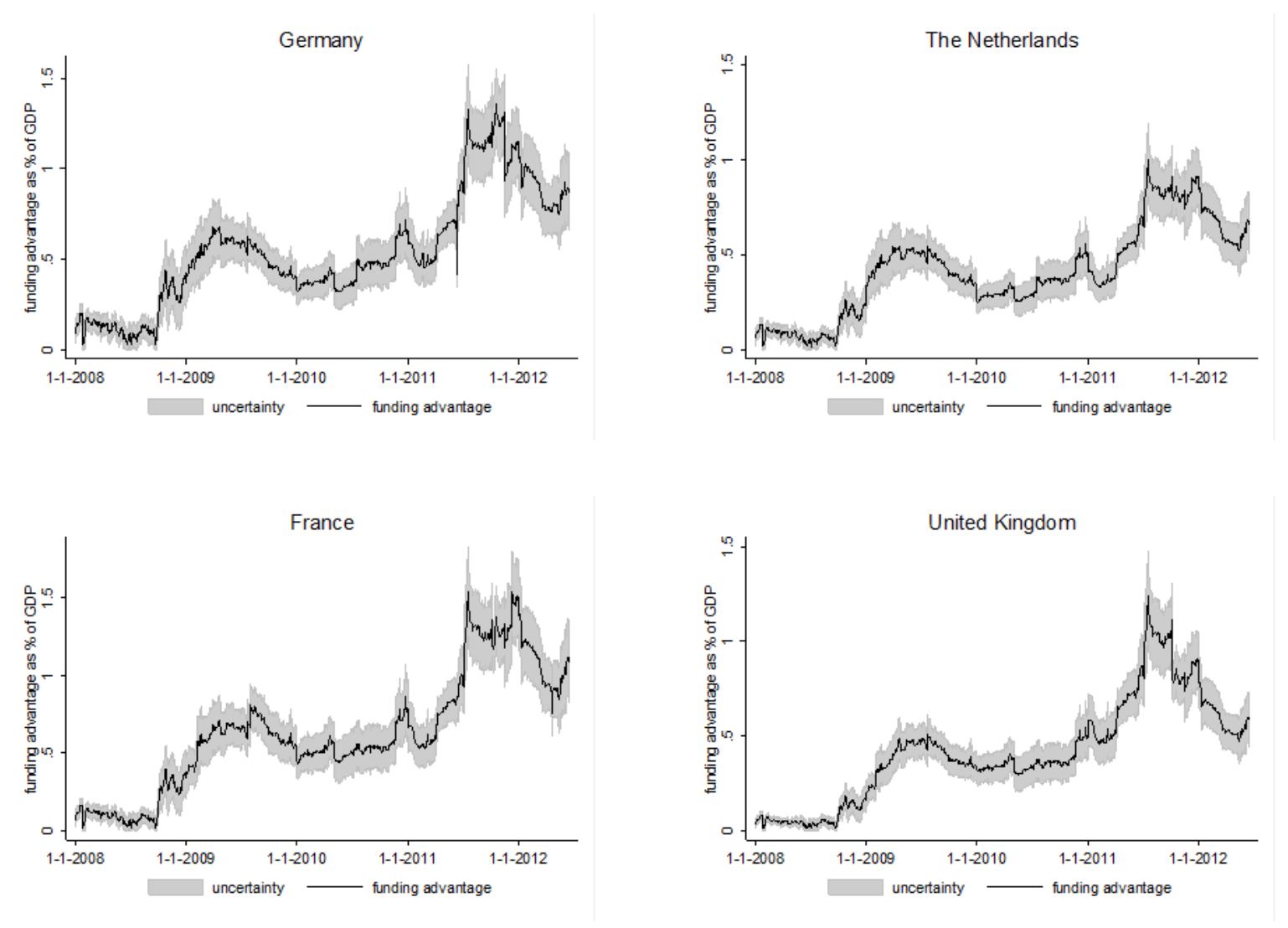
Figure 7: funding advantage per country (Spain, Ireland*, Italy, and Portugal)
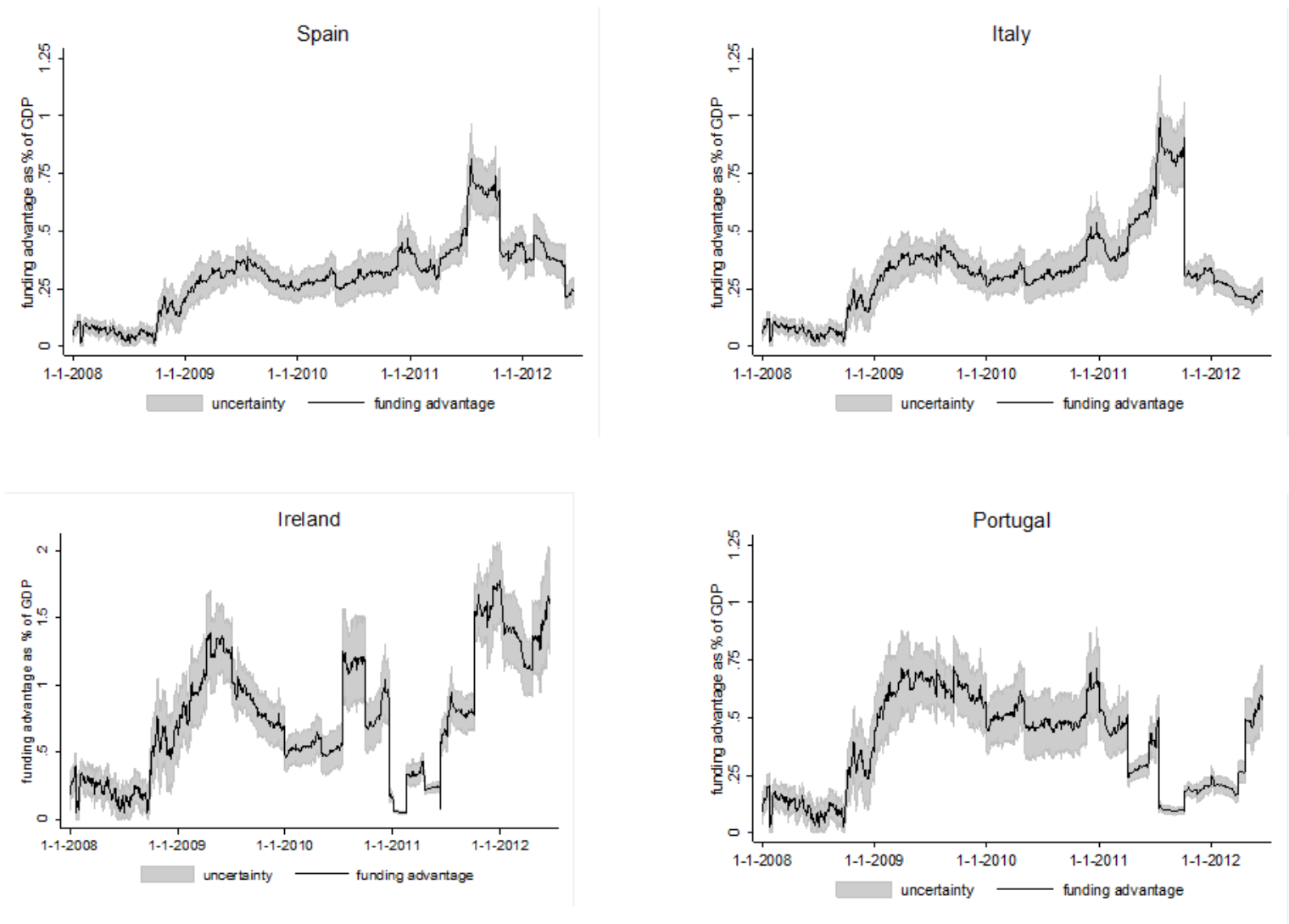

*note that the figure for Ireland is drawn on a different scale 
Figure 8: funding advantage vs. BFS rating

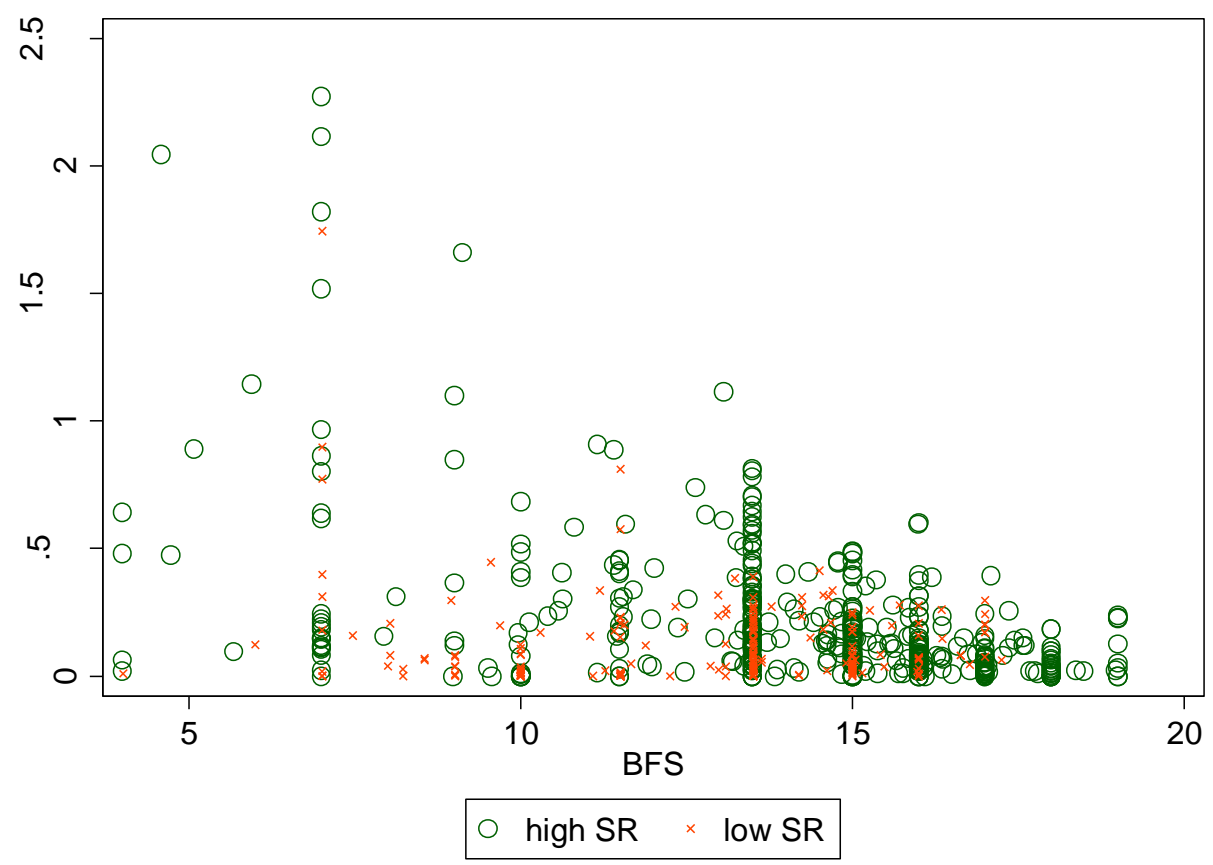

Figure 9: funding advantage vs. sovereign rating

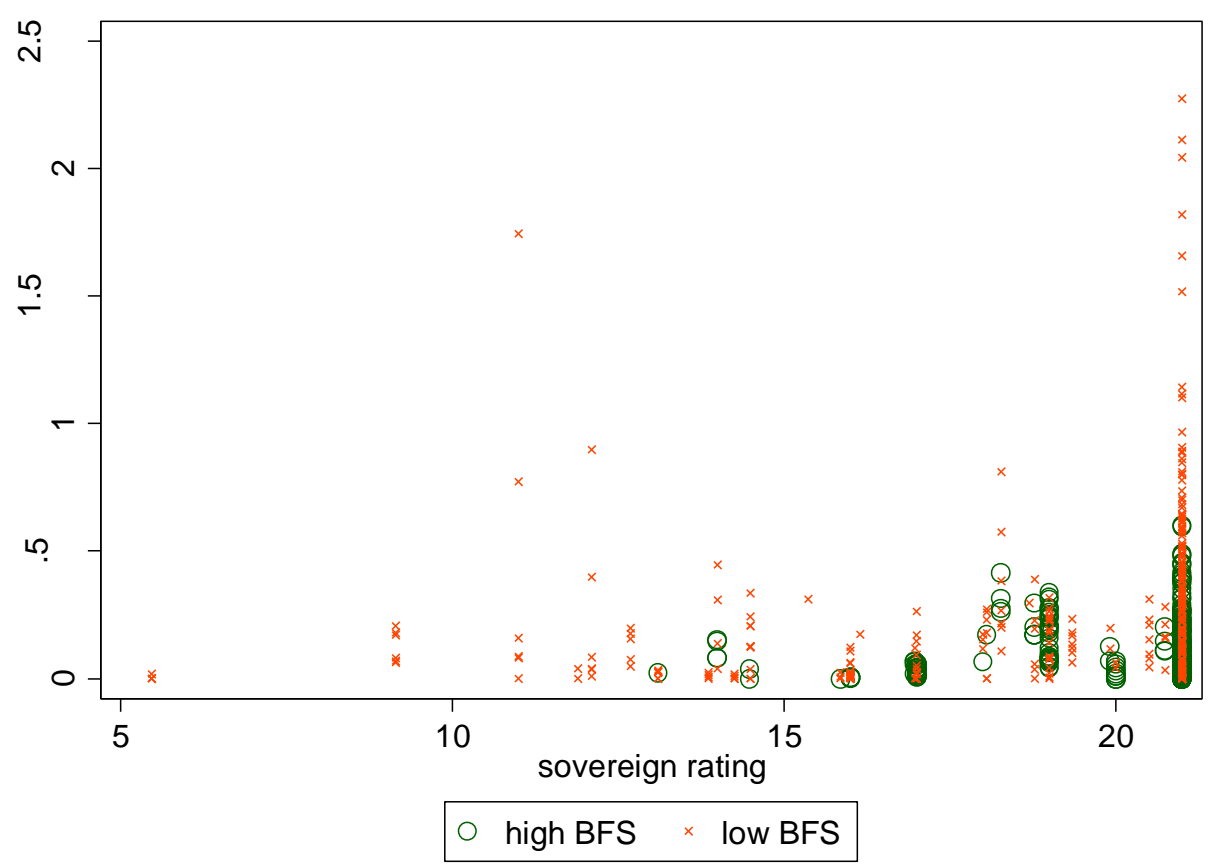




\section{Appendix D: Comparison with other estimates}

Our results are directly comparable to the findings of Schich and Lindh (2012) and Noss and Sowerbutts (2012) since we use the same funding advantage approach. In order to make our results comparable to the findings in other studies we need to calculate the funding advantage as a percentage of the bank's total assets. Table $\mathrm{C}_{1}$ shows the average annual funding advantages for the banks in our sample as a percentage of total assets.

Table $\mathrm{C}_{1}$ : average yearly funding advantage of banks (\% of total assets)

\begin{tabular}{lccc}
\hline \hline & funding advantage & lower bound & upper bound \\
\hline \hline 2008 & 0.05 & 0.02 & 0.07 \\
2009 & 0.16 & 0.13 & 0.20 \\
2010 & 0.15 & 0.11 & 0.19 \\
2011 & 0.31 & 0.25 & 0.37 \\
2012 & 0.30 & 0.24 & 0.35 \\
average & $\mathbf{0 . 1 8}$ & $\mathbf{0 . 1 4}$ & $\mathbf{0 . 2 2}$ \\
\hline \hline
\end{tabular}

Based on this numbers, we assume that the average annual funding advantage related to the TBTF guarantee is in the range of $0.14-0.22$ percent of the bank's total assets during the period 2008-2012.

Other studies rely on events that result in a sudden change of the TBTF status of the bank. Mergers between banks (Penas and Unal, 2004; Brewer and Jagtiani, 2011) and the decision by the Comptroller of the Currency in the US in 1984 (O'Hara and Shaw, 1990) provide examples of events that suddenly change the TBTF status of a bank. We calculate the net present value of a $0.14-0.22$ percent reduction in funding costs from period $t=1$ until infinity to make our results comparable to the value of a sudden change in the TBTF status:

$$
\frac{0.14}{r}=\sum_{t=1}^{\infty} \frac{0.14}{(1+r)^{t}}<N P V<\sum_{t=1}^{\infty} \frac{0.2}{(1+r)^{t}}=\frac{0.22}{r}
$$

Taking a value for $r$ of $5 \%$ yields an estimate for the net present value of obtaining the TBTF status that varies between 2.8 and 4.4 percent of the bank's total assets.

\section{Schich and Lindh (2012)}

Schich and Lindh (2012) estimate the funding advantage at one particular moment in time (end of March, 2012). Their lower bound estimates, which only include debt of the rated bank entity and not of subsidiaties, vary between $0.02 \%$ of GDP (Belgium) and $0.95 \%$ of GDP (Germany). We calculate the average funding advantage of the banks in our sample in March 2012. Table C2 provides a comparison of the estimated funding advantages per country in Schich and Lindh (2012) and in our paper. 


\begin{tabular}{|c|c|c|}
\hline Country & Schich and Lindh (2012) & Our results \\
\hline$\overline{S E}$ & $0.65(6)$ & $0.91(4)$ \\
\hline DE & $0.95(17)$ & $0.85(11)$ \\
\hline FR & $0.35(7)$ & $1.02(7)$ \\
\hline AT & $0.70(6)$ & $0.62(8)$ \\
\hline GB & $0.40(14)$ & $0.57(11)$ \\
\hline NL & $0.40(8)$ & $0.62(7)$ \\
\hline IT & $0.30(13)$ & $0.24(11)$ \\
\hline $\mathrm{BE}$ & $0.02(2)$ & $0.27(4)$ \\
\hline ES & $0.10(10)$ & $0.41(8)$ \\
\hline IE & $0.05(3)$ & $1.23(5)$ \\
\hline
\end{tabular}

For Germany, Austria, and Italy the numbers have the same order of magnitude. For the other countries, our estimates are higher. There are four explanations that can potentially explain the differences between the two studies. In the first place, the samples are not identical. Secondly, the differences can be related to the definition of the Bank Financial Strength (BFS) rating. Schich and Lindh (2012) use the adjusted BFS rating, which already incorporates the possibility of external support from a parent company. Using this adjusted BFS rating results in rating uplifts that are on average 0.4 notches smaller compared to the uplifts found when using the standard BFS rating. Thirdly, the measures of outstanding debt are not the same in the two studies. While we use "long-term funding" from Bankscope, Schich and Lindh (2012) use "outstanding bonds and loans" issued in the market which is available from Bloomberg. Finally, we employ a different strategy to find the relationship between ratings and funding costs.

\section{Noss and Sowerbutts (2012)}

Noss and Sowerbutts (2012) estimate the funding advantage of the four largest UK banks to be about 5, 25, 125, and 40 billion GBP in 2007, 2008, 2009, and 2010 respectively. We find much smaller average funding advantages of 1.3, 6.2, and 6.2 billion EUR for the years 2008, 2009, and 2010 respectively (upper bounds of 1.9, 7.5, and 7.8 billion EUR). This is mainly explained by the fact that we find much smaller reductions in interest rates corresponding to a given rating uplift.

\section{O'Hara and Shaw (1990)}

O'Hara and Shaw look at the effect of the decision by the US Comptroller of the Currency in 1984 on bank equity values of 11 large US banks. They find positive residual returns on equity of $1.3 \%$ on day of announcement. This would imply that the stockholders expect the NPV of all future profits to be $1.3 \%$ higher as a result of the change in the TBTF status of the bank. We find an effect of $2.8 \%-4.4 \%$ lower funding costs in terms of NPV. The question is how this number translates into higher profits. Given that there is some competition between banks, a part of the lower funding costs will accrue to the customers. If we also 
assume that competition is not perfect, it is also likely that the lower funding costs will partly accrue to the banks in the form of higher profits. We cannot determine how the gain resulting from the lower funding costs will be distributed between the bank and its customers, but the $1.3 \%$ residual return on equity does not violate our findings.

\section{Pop and Pop (2009)}

Pop and Pop (2009) investigate the effect on stock prices of the five largest Japanese banks as a result of the bailout of Resona Holding. They find negative abnormal returns on the event day of $-5.6 \%$. One day later, the government announces that shareholders would not incur any losses, resulting in positive abnormal returns of $8.4 \%$. The net effect is thus a positive abnormal return of $2.8 \%$. This number could also be comparable to our findings depending on how the extra profits due to lower funding costs are distributed between consumers and the bank.

\section{Schweikhard and Tsesmelidakis (2012)}

The authors find an annual funding advantage equal to $7.5 \%$ of total debt issuance on average over the period 2007-2010 for a total of 27 US banks. This number is best comparable to our average funding advantage estimate which only includes the interest advantage on long-term funding. Our estimate of $0.18 \%$ funding advantage annually is much lower, but this number is expressed as a percentage of total assets. If we express the size of the funding advantage in terms of total long-term funding, we find that the average funding advantage per bank equals $0.92 \%$. Note that this is simply equivalent to the average yield reduction as we calculate $\frac{\text { yield reduction } * \text { funding }}{\text { funding }}$. From Table $\mathrm{C}_{1}$ it is clear that this number might vary over time, but even when we take this into account, the number found by Schweikhard and Tsesmelidakis (2012) is much larger than our estimate of the funding advantage.

\section{Brewer and Jagtiani (2011)}

We can compare our estimates to the so-called 'Case I' in Brewer and Jagtiani (2011). ' Case I' includes banks that become TBTF after a merger. The number of 'Case I' observations in their paper equals eight. Total assets of the acquirer are on average 73.061 USD million. Total assets of the target bank are one average 63.104 UDS billion. Banks pay a total TBTF merger premium equal to 15.3 billion USD. The total assets of all acquiring banks are $8^{*} 73.061=584.488$ million. Now assume that the merging bank expects to make a profit because of obtaining the TBTF status. The banks estimate the net present value of this extra future profits to be 15.3 billion / 584 billion $=2.6 \%$ of the (original) total assets of the eight acquiring banks that become TBTF after the merger. Again, this number could be 
in line with our estimate of $2.8 \%-4.4 \%$ lower funding costs as it is likely that the lower funding costs at least partly accrue to the customers of the bank.

\begin{abstract}
Anginer and Warburton (2011)
Anginer and Warburton (2011) find the annual funding cost advantage to be 16 basis points from 1990-2007, 88 basis points from 2008-2010, with a peak at 100 basis point in 2008 for a sample of 232 US financial institutions. In our paper the average yield reduction was $0.63 \%$ (63 basis points) over the period 2008-2010 for all 151 European banks in our sample. When we also include 2011, the average yield reduction increases to $0.87 \%$ ( 87 basis points). We can conclude that these numbers are highly comparable although this should not necessarily be the case since we analyze an European dataset while Anginer and Warburton (2011) analyze a sample of US financial institutions.
\end{abstract}


Publisher:

CPB Netherlands Bureau for Economic Policy Analysis

P.O. Box $80510 \mid 2508$ GM The Hague

$\mathrm{T}(070) 3383380$

April 2013 | ISBN 978-90-5833-594-4 